Prepared in cooperation with the City of Cold Spring, Minnesota

\title{
Effects of Ground-Water Withdrawals on Flow in the Sauk River Valley Aquifer and on Streamflow in the Cold Spring Area, Minnesota
}

Water-Resources Investigations Report 01-4111 
Effects of Ground-Water Withdrawals on Flow in the Sauk River Valley Aquifer and on Streamflow in the Cold Spring Area, Minnesota

\author{
By R. J. Lindgren
}

Water-Resources Investigations Report 01-4111 


\section{U.S. DEPARTMENT OF THE INTERIOR}

Gale A. Norton, Secretary

\section{U.S. GEOLOGICAL SURVEY}

Charles G. Groat, Director

Use of brand names in this report is for identification purposes only and does not constitute endorsement by the U.S. Geological Survey.

Mound View, Minnesota, 2001

For additional information write to:

U.S. Geological Survey

District Chief

2280 Woodale Drive

Mounds View, MN 55112

Copies of this report can be purchased from:

\section{U.S. Geological Survey}

Branch of Information Services

Box 25286, MS 517

Federal Center

Denver, CO 80225

Information regarding the USGS is available on the Internet via the World Wide Web.

You may connect to the USGS Home Page using the Universal Resource Locator (URL) at http://wwwrvares.er.usgs.gov.

You may also connect to the Minnesota District Home Page at http://mn.water.usgs.gov/.

For more information on all USGS reports and products (including maps, images, and computerized data), call 1-888-ASK-USGS

Water-Resources Investigations Report 01-4111 


\section{CONTENTS}

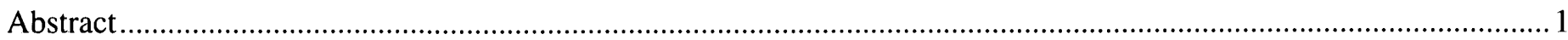

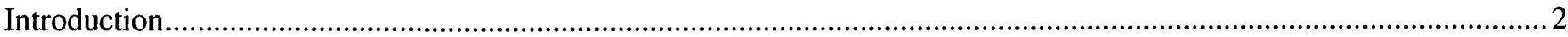

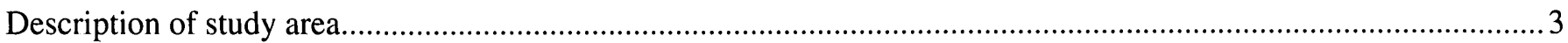

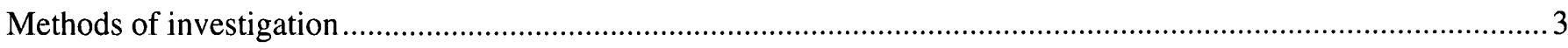

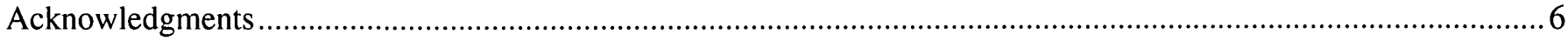

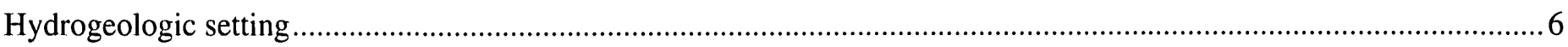

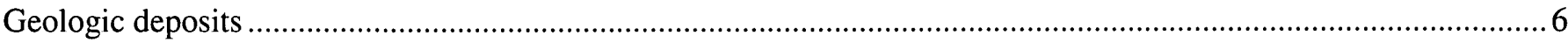

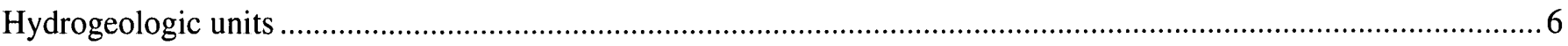

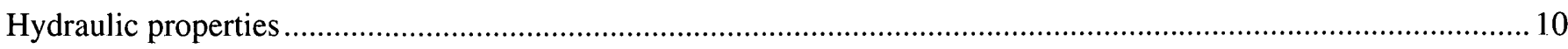

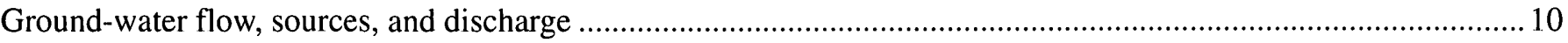

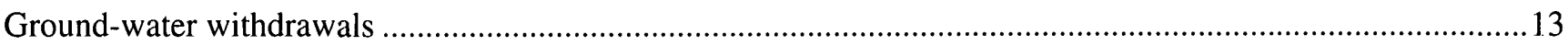

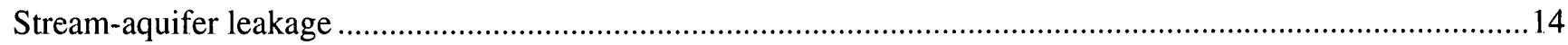

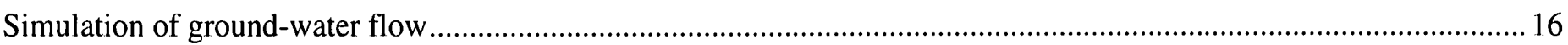

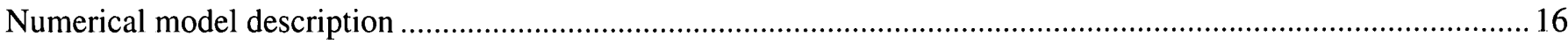

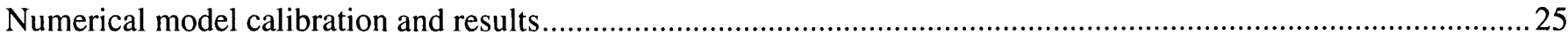

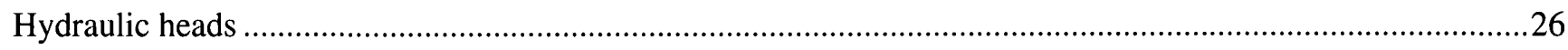

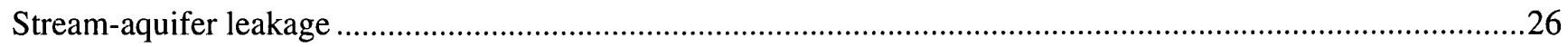

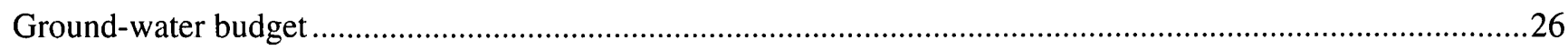

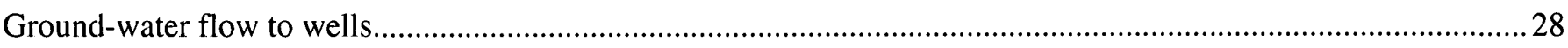

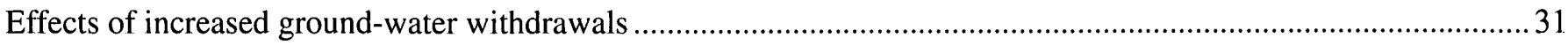

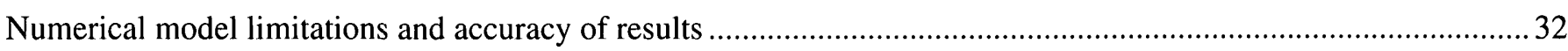

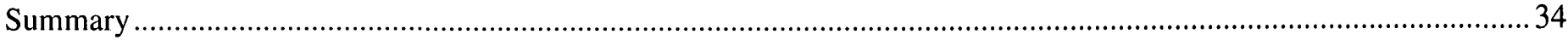

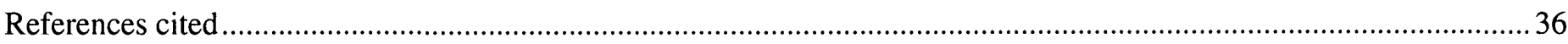

\section{ILLUSTRATIONS}

Figures 1-9a. Maps showing:

1. Location of study area, wells, and streamflow and stream-stage measurement sites, Cold Spring area, Minnesota.

1a. Location of wells, and streamflow and stream-stage measurement sites near Cold Spring and Gold'n Plump Poultry Processing Plant, Cold Spring area, Minnesota ......................................................5

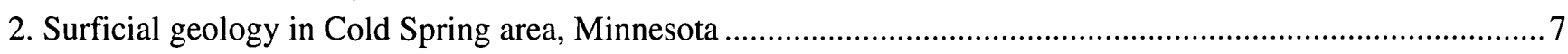

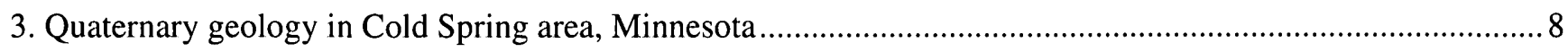

4. Measured and simulated potentiometric surface of the upland surficial aquifer, December 1998, Cold Spring area, Minnesota.

5. Measured and simulated potentiometric surface of the Sauk River Valley aquifer, December 1998, Cold Spring area, Minnesota..

5a. Measured and simulated potentiometric surface of the Sauk River Valley aquifer, near Cold Spring and Gold'n Plump Poultry Processing Plant, December 1998, Cold Spring area, Minnesota ........................ 12

6. Grid for finite-difference ground-water-flow model, Cold Spring area, Minnesota....................................... 17

7. Extent, boundary conditions, and calibrated horizontal hydraulic conductivity zones for ground-waterflow model layer 1, Cold Spring area, Minnesota

8. Extent, boundary conditions, and calibrated vertical hydraulic conductivity zones for ground-water-flow model layer 2, Cold Spring area, Minnesota.

9. Extent, boundary conditions, and calibrated horizontal hydraulic conductivity zones for ground-waterflow model layer 3, Cold Spring area, Minnesota 


\section{ILLUSTRATIONS--CONTINUED}

9a. Boundary conditions and calibrated horizontal hydraulic conductivity zones for ground-waterflow model layer 3 near Cold Spring and Gold'n Plump Poultry Processing Plant, Cold Spring area, Minnesota.

10. Extent, boundary conditions, and calibrated horizontal hydraulic conductivity zones for ground-waterflow model layer 4, Cold Spring area, Minnesota

11. Simulated altitude of potentiometric surface of Sauk River Valley aquifer and contributing areas of ground-water flow to water-supply wells, 1998 pumpage, Cold Spring area, Minnesota.

11a. Simulated altitude of potentiometric surface of Sauk River Valley aquifer and contributing areas of ground-water flow to water-supply wells near Cold Spring, and Gold'n Plump Poultry Processing Plant, 1998 pumpage, Cold Spring area, Minnesota

12. Simulated altitude of potentiometric surface of Sauk River Valley aquifer, contributing areas, and 20-year time-of-travel zones of ground-water flow to water-supply wells, projected pumpage, Cold Spring area, Minnesota

12a. Simulated altitude of potentiometric surface of Sauk River Valley aquifer, contributing areas, and 20-year time-of-travel zones of ground-water flow to water-supply wells near Cold Spring and Gold'n Plump Poultry Processing Plant, projected pumpage, Cold Spring area, Minnesota.....

\section{TABLES}

1. Stream discharge and measured and simulated stream-aquifer leakage under low-flow conditions during 1998-99, Cold Spring area, Minnesota

2. Initial and final calibrated values of hydraulic properties used in ground-water-flow model of aquifer system, Cold Spring area, Minnesota

3. Simulated water budgets from ground-water-flow model of aquifer system with 1998 and projected pumpage conditions, Cold Spring area, Minnesota

4. Simulated leakage between model layers from ground-water-flow model of aquifer system with 1998 and projected pumpage conditions, Cold Spring area, Minnesota

\section{CONVERSION FACTORS, ABBREVIATED WATER-QUALITY UNITS AND SEA LEVEL DATUM}

$\begin{array}{lc}\text { Multiply } & \text { By } \\ \text { inch (in.) } & 2.54 \\ \text { inch per year (in./yr) } & 2.54 \\ \text { foot (ft) } & .3048 \\ \text { foot squared per day }\left(\mathrm{ft}^{2} / \mathrm{d}\right) & .09290 \\ \text { cubic foot per second }\left(\mathrm{ft}^{3} / \mathrm{s}\right) & .02832 \\ \text { gal (gal) } & 3.785 \\ \text { gallon per minute }(\mathrm{gal} / \mathrm{min}) & 3.785 \\ \text { mile (mi) } & 1.609 \\ \text { square mi }\left(\mathrm{mi}^{2}\right) & 2.590\end{array}$

To obtain

centimeter centimeter per year meter meter squared per day cubic meter per second liter liter per minute kilometer square kilometer

Chemical concentrations of substances are given in metric units of milligrams per liter $(\mathrm{mg} / \mathrm{L})$ and micrograms per liter $(\mu \mathrm{g} / \mathrm{L})$. Milligrams and micrograms per liter express the concentration of the chemical constituent as a mass (mg or $\mu \mathrm{g}$ ) per unit volume (L). One thousand micrograms per liter is equivalent to 1 milligram per liter.

Sea level: In this report "sea level" refers to the National Geodetic Vertical Datum of 1929 (NGVD of 1929)—a geodetic datum derived from a general adjustment of the first-order nets of both the United States and Canada, formerly called Sea Level Datum of 1929. 


\title{
Effects of Ground-Water Withdrawals on Flow in the Sauk River Valley Aquifer and on Streamflow in the Cold Spring Area, Minnesota
}

\author{
By Richard J. Lindgren
}

\section{ABSTRACT}

The U. S. Geological Survey, in cooperation with the city of Cold Spring, Minnesota conducted a study during 1998-99 to: (1) determine the contributing areas of groundwater flow to high-capacity wells, (2) delineate the 10-, $20-$, and 30-year time-of-travel zones to high-capacity wells, and (3) determine changes in streamflow in the Sauk River due to ground-water withdrawals. Surficial aquifers underlie a portion of the uplands in the north-central part of the study area and the Sauk River Valley. The upland surficial aquifer is unconfined, with saturated thicknesses ranging from 6 to 37 feet. The Sauk River Valley aquifer consists of hydraulically connected sand and gravel units:

(1) the generally continuous surficial unconfined unit underlying the Sauk River Valley and (2) buried confined units that are overlain by till or lake clays in the upland areas. Maximum saturated thickness of the Sauk River Valley aquifer is about 50 feet. Thicknesses of the buried units are generally 10 to 20 feet.

Ground-water flow in the upland surficial aquifer is (1) to the south and southeast toward the margins of the aquifer and (2) toward an unnamed creek valley in the northwestern part of the study area. Ground-water flow in the Sauk River Valley aquifer is from upland areas toward the Sauk River and the connected chain of lakes. Based on hydrograph analysis, ground-water recharge rates to the aquifers during 1999 ranged from 5.3 to 8.6 inches per year, with an average value of 7.0 inches per year.

Streamflow measurements indicated net gains of 44.8 and 25.8 cubic feet per second for the Sauk River from Cold Spring to Rockville during October 1998 and August 1999 , respectively. In general, the Sauk River probably is a gaining stream in all reaches, except for the reach adjacent to the Gold'n Plump Poultry Processing Plant well field. Ground-water withdrawals from the well field induce infiltration of water from the Sauk River to the underlying aquifer. The measured gains in streamflow for Brewery Creek were 2.75 and 2.25 cubic feet per second during October 1998 and August 1999, respectively.

A numerical ground-water-flow model was constructed and calibrated for steady-state conditions. Based on the calibrated model, areal recharge accounts for 51.5 percent of the sources of water to the aquifers in the Cold Spring area and inflow through constant-head boundaries contributes 45.8 percent. The largest discharges from the aquifers are leakage from the Sauk River Valley aquifer to the Sauk River and Brewery Creek (53.7 percent) and outflow through constant-head boundaries (33.1 percent).

The simulated contributing areas for selected watersupply wells in the Cold Spring area generally extend to and possibly beyond the model boundaries to the north and to the southeast. The contributing areas for the Gold'n Plump Poultry Processing Plant supply wells extend: (1) to the Sauk River, (2) to the north to and possibly beyond to the northern model boundary, and (3) to the southeast to and possibly beyond the southeastern model boundary. The primary effects of projected increased ground-water withdrawals of 0.23 cubic feet per second ( 7.5 percent increase) were to: (1) decrease outflow from the Sauk River Valley aquifer through constant-head boundaries and (2) decrease leakage from the valley unit of the Sauk River Valley aquifer to the streams. No appreciable differences were discernible between the simulated steady-state contributing areas to wells with 1998 pumpage and those with the projected pumpage. 


\section{INTRODUCTION}

Increased demand for ground water in the Cold Spring area in central Minnesota has resulted in the increased development of glaciallydeposited aquifers, hereinafter termed glacial aquifers. These aquifers, composed of surficial and buried sand and gravel, underlie the Sauk River Valley in the Cold Spring area and are utilized as sources of water supply. The Minnesota Department of Health $(\mathrm{MDH})$ and public and private water suppliers are concerned about the effects of ground-water withdrawals from high-capacity wells on water levels in the aquifers, streamflow in the Sauk River, and potential sources of contamination to water-supply wells. Potential sources of contaminated water to high-capacity watersupply wells in the Cold Spring area, some of which are located near the Sauk River, include both contaminated ground water and the Sauk River. Areas contributing groundwater to high-capacity wells need to be delineated so that land use within the contributing areas can be managed to reduce the risk of water-quality degradation. Of particular concern to the $\mathrm{MDH}$ and water managers is the extent and sources of nitrate contamination in the aquifers and the Sauk River. A better understanding of ground-water flowpaths and groundwater travel times in the Cold Spring area and the extent of contributing areas to public supply wells is needed to manage the water supplies and prevent contamination of public watersupply wells. Changes in contributing areas and time-of-travel zones as a result of anticipated development also need to be assessed.

During August 1996, nitrate concentrations exceeded the maximum contaminant level of 10 milligrams per liter as nitrogen ( $\mathrm{mg} / \mathrm{L}$ as $\mathrm{N})$ set by the U.S. Environmental Protection
Agency (USEPA) (1996) in water sampled from Cold Spring municipal well CS1 (Minnesota Department of Health, 1999). Cold Spring municipal well CS2 also has shown elevated concentrations of nitrate, ranging from 7 to $8 \mathrm{mg} / \mathrm{L}$ as $\mathrm{N}$ (Minnesota Department of Health, 1999). These two wells make up the city's primary well field. In addition, sampling of other public and private wells by local well drillers, Stearns County Environmental Services Department, and the Minnesota Department of Agriculture (MDA) points to a number of other areas around the community where local ground water has nitrate concentrations approaching or exceeding the maximum contaminant level of $10 \mathrm{mg} / \mathrm{L}$ as N. During October 1996, monitoring of eight private wells located in the vicinity of the proposed new well site for Cold Spring municipal well CS4 indicated nitrate concentrations ranging from $<1.0$ to $6.2 \mathrm{mg} / \mathrm{L}$ as N. Pesticide monitoring indicated low concentrations of atrazine in the Cold Spring water system. During 1991, MDH monitoring indicated low concentrations of volatile organic compounds in two private water supply systems (Gold'n Plump Poultry Processing Plant and Cold Spring Granite Company).

The Wellhead Protection (WHP) Program is a provision in the 1986 Amendments to the Safe Drinking Water Act designed to assist State agencies in protecting areas surrounding wells against infiltration, percolation, and transport of contaminants that may have adverse effects on human health. The USEPA prepared a guidebook (U.S. Environmental Protection Agency, 1987) to provide technical guidance on the hydrologic aspects of WHP in the United States. For the purposes of WHP, three types of recharge areas have been defined: the zone of transport, the zone of con- tribution, and the zone of influence (U.S. Environmental Protection Agency, 1987). The time required for a contaminant to travel between points in an aquifer can be identified using maps showing lines of equal advective travel time. A zone of transport (time-of-travel zone), therefore, is defined by the area around a pumped well bounded by lines of equal travel time. The zone of contribution (contributing area) for a highcapacity well (greater than $\left.200 \mathrm{gal} / \mathrm{min}\left(0.44 \mathrm{ft}^{3} / \mathrm{s}\right)\right)$ is defined as that part of a ground-water-flow system supplying water to a well. The contributing area could be thought of as a time-of-travel zone for infinite travel time. The zone of influence is the area of declines in hydraulic head resulting from the withdrawal of water from a well.

To address these needs and concerns, and to further the understanding of stream-aquifer systems, the U.S. Geological Survey (USGS), in cooperation with the City of Cold Spring, conducted a study during 1998-99. The objectives of this study were to: (1) determine the contributing area of ground-water flow to highcapacity wells under current and projected development conditions, (2) delineate the 20-year time-of-travel zones to high-capacity wells under current and projected development conditions, and (3) aid in understanding the interaction between the Sauk River Valley aquifer and the Sauk River and Brewery Creek. This report describes the results of field data collection during 1998-99, the sources and types of data used in constructing a steady-state numerical groundwater-flow model, the model calibration process, and the results of model simulations. 


\section{Description of Study Area}

The study area covers about $55 \mathrm{mi}^{2}$ in southeastern Stearns County in central Minnesota (fig. 1). The city of Cold Spring, with a population of approximately 4,000 , is located near the center of the study area. The study area is drained by the Sauk River, which flows from west to east across the study area and whose confluence with the Mississippi River is about $15 \mathrm{mi}$ northeast of the study area. Average annual precipitation in the study area is 27 in. (Baker and Kuehnast, 1978). Of this amount, about 4.5 in. leaves the Sauk River Basin as runoff (Baker and others, 1979). The nearest USGS streamflow-gaging station on the Sauk River (station number 05270500 ) is located about $8 \mathrm{mi}$ downstream of Cold Spring. The average annual flow in the Sauk River at this point is $305 \mathrm{ft}^{3} / \mathrm{s}$ (Mitton and others, 1999). The minimum recorded discharge is $0.3 \mathrm{ft}^{3} / \mathrm{s}$ and the maximum discharge is $9,100 \mathrm{ft}^{3} / \mathrm{s}$. Brewery Creek, a tributary to the Sauk River, flows to the southeast through Cold Spring. A chain of lakes extending from Knaus Lake on the east to Horseshoe Lake on the west is located in the southwestern part of the study area. The Sauk River flows into the chain of lakes near the western boundary of the study area and flows out of Knaus Lake south of Cold Spring (fig. 1).

Topography is rolling to undulating in upland areas and steep near streams and drainageways. The topography is relatively flat along the Sauk River Valley. In the study area, the valley is much wider on the northwest side of the river than on the southeast side. Relatively steep bluffs (an escarpment with about $70 \mathrm{ft}$ change in altitude) dip down to the Sauk River Valley about 1 mile northwest of the downtown area of Cold Spring and along the southeast side of the Sauk River. There is a lower river terrace (about $20 \mathrm{ft}$ above river level) immediately north of Cold Spring. Land use in the Cold Spring area is evenly divided between developed and undeveloped land. About 25 percent of the area is used for agriculture. Undeveloped land other than agriculture includes forest, wetlands, and surface-water bodies.

\section{Methods of Investigation}

Existing data on the hydrogeology and hydraulic properties of the ground-water system in the study area were compiled from a variety of sources including test-hole and waterwell logs, geologic maps, State and Federal data bases, and published reports. New data collected for this study includes test drilling and well installation, water levels, and stream discharge. A numerical ground-waterflow model was constructed using information from test-hole logs, water-well logs, and geologic maps.

Test-hole and water-well logs were obtained from the Minnesota Geological Survey's County Well Index for Stearns County, the USGS Ground Water Site Inventory data base, consulting reports, and the MDH. Twenty-one 2-inch-diameter observation wells were installed for this study. All but one of the observation wells were screened in surficial sand and gravel deposits. A pair of nested wells was installed near the Sauk River at the Gold'n Plump Poultry Processing Plant site and a set of three nested wells was installed near Cold Spring municipal wells CS1 and CS2 (fig. 1a). The deeper well of the pair of nested wells at the Gold'n Plump Poultry Processing Plant site was screened in a lower-permeability deposit underlying the surficial sand and gravel deposits and overlying granitic bedrock.

Water levels were measured monthly during November 1998 through October 1999 in the 21 observation wells installed for this study and in 7 observation wells screened in surficial sand and gravel deposits that had been installed prior to this study (fig. 1). Water levels were measured twice during October 1998 through February 1999 in 31 domestic and commercial wells (fig. 1). Eight of the 31 domestic and commercial wells are screened in surficial sand and gravel deposits in the north-central part of the study area, 19 are screened in surficial sand and gravel deposits in the Sauk River Valley and buried sand and gravel deposits in the adjacent uplands, and 4 are open to the granitic bedrock. Water levels measured in the 28 observation wells and 24 of the domestic and commercial wells were used to calibrate the numerical ground-water-flow model.

Stream- or lake-stage measurements were made monthly during November 1998 through October 1999 (if open-water conditions existed) at 5 sites on the Sauk River, 3 sites on the chain of lakes, and 2 sites on Brewery Creek (fig. 1). One of the sites on the Sauk River was at Rockville, located about $1 \mathrm{mi}$ east of the study area.

The altitudes of all water-level measurement points were determined by surveying from nearby benchmarks by the USGS (Greg Payne, written commun., 1999). Altitudes of measuring points were measured with a precision of $0.1 \mathrm{ft}$.

Synoptic sets of low-flow measurements were made to quantify streamflow gains and losses for reaches of the Sauk River and Brewery Creek. Streamflow measurements were made at nine sites on the Sauk 


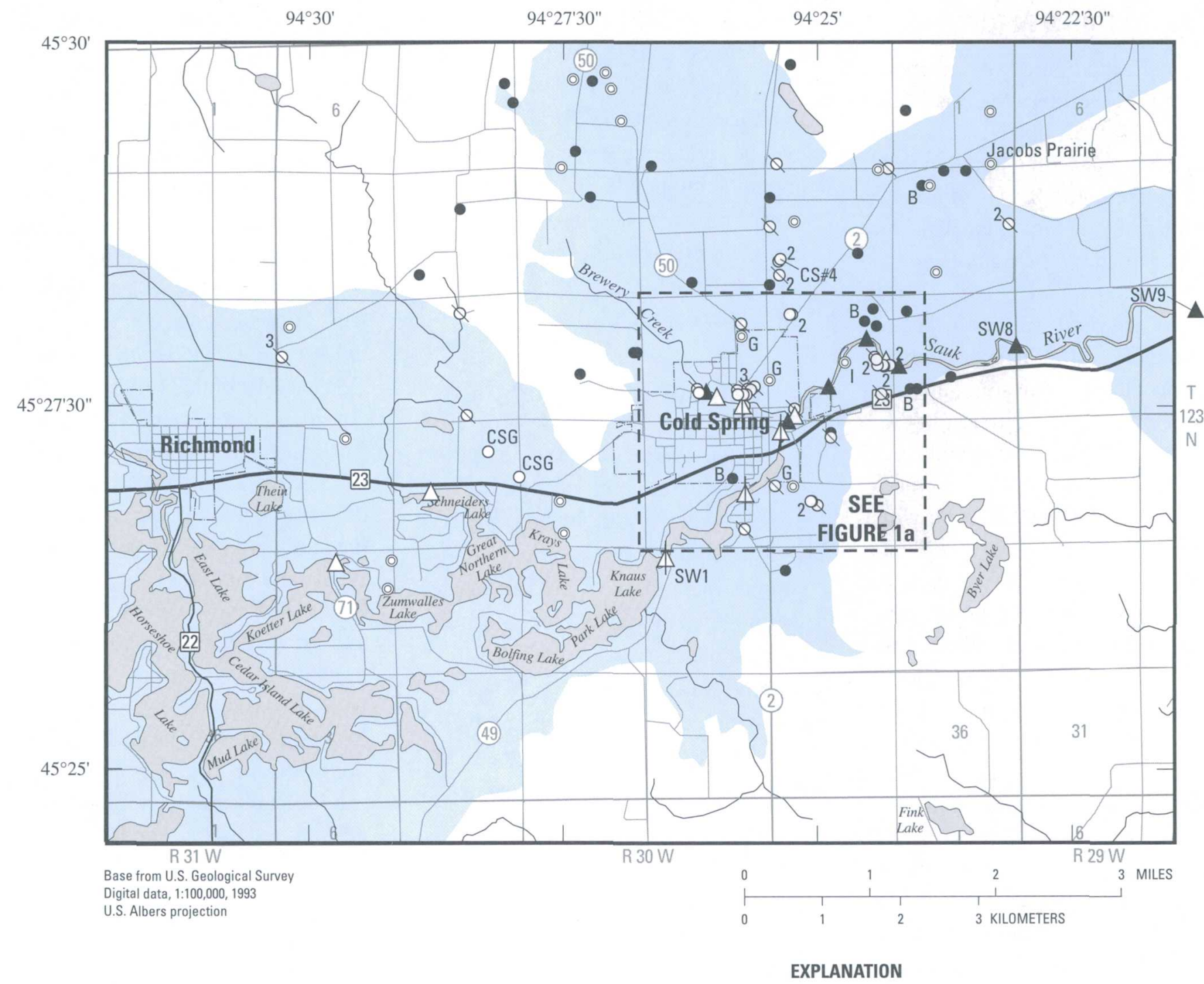

Area where valley unit of Sauk river Valley aquifer is present

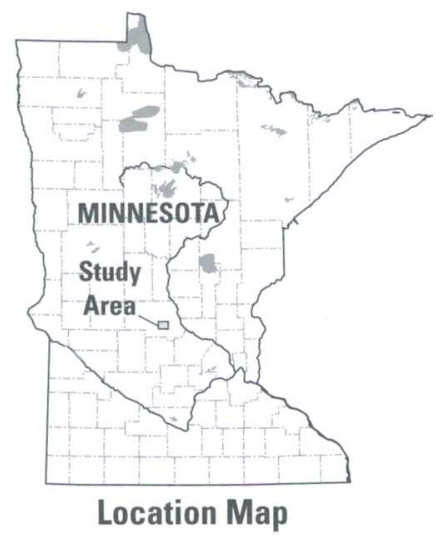

- Domestic or commercial well (B indicates well open to Precambrian bedrock)

$Q_{2}$ Observation well (number indicates nested wells)

${ }_{2} \mathrm{O}^{\mathrm{CS}}$ WHP partnership water-supply well (Number indicates multiple wells at a site. CSG indicates Cold Spring Granite Company supply well. CS indicates Cold Spring municipal well)

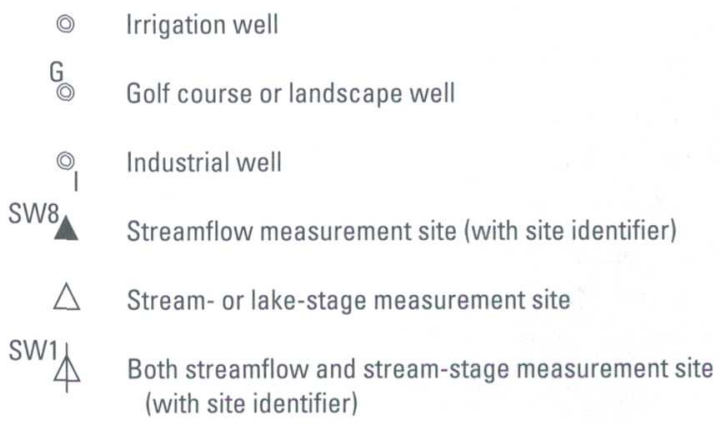

Figure 1. Location of study area, wells, and streamflow and stream-stage measurement sites, Cold Spring area, Minnesota. 


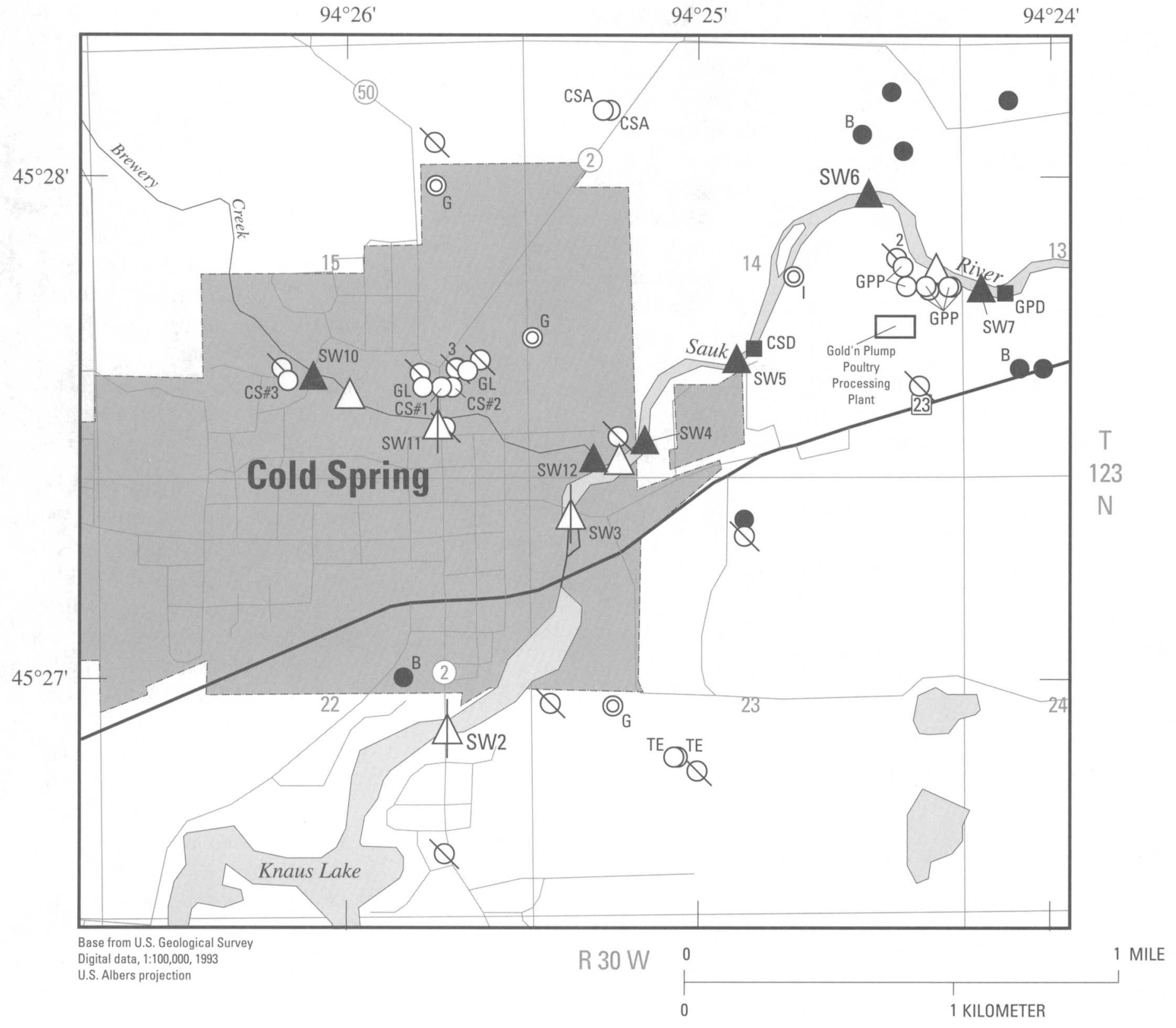

EXPLANATION

$\mathrm{C}^{\mathrm{B}}$

Domestic or commercial well ( $B$ indicates well open to precambrian bedrock)

$Q^{2}$ Observation well (number indicates nested wells)

$\mathrm{O}^{\mathrm{CS}}$

WHP partnership water-supply well

GL indicates Gluek Brewing Company supply well CS indicates Cold Spring municipal well

TE indicates Town's Edge Mobile Home Park supply well GPP indicates Gold'n Plump Poultry supply well CSA indicates Cold Spring Alano Society supply well

(C) Irrigation well

G) Golf course or landscape well

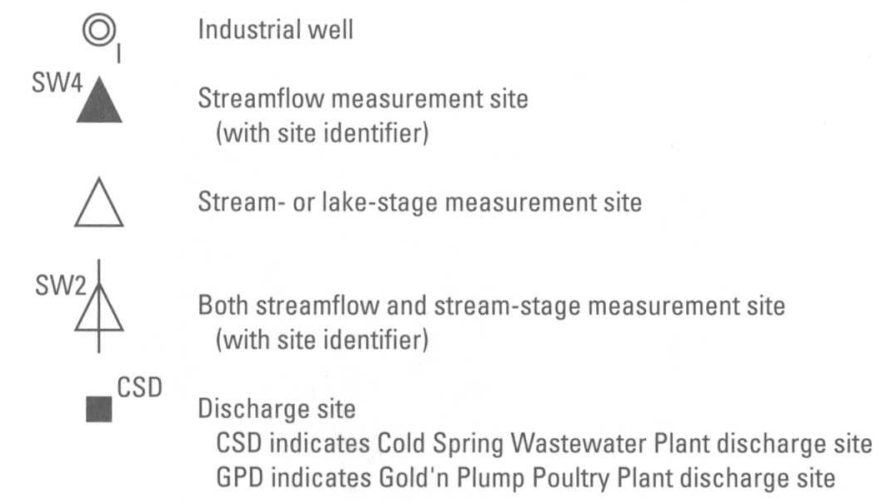

Figure 1a. Location of wells, and streamflow and stream-stage measurement sites near Cold Spring and Gold'n Plump Poultry Processing Plant, Cold Spring area, Minnesota. 
River and at three sites on Brewery Creek during October 1998 and August 1999 (fig. 1). The estimated accuracy of individual current-meter streamflow measurements was 5 percent for measurements rated good and 8 percent for measurements rated fair (Pelletier, 1988). The measured streamflow gains and losses were used in the calibration of the numerical ground-water-flow model.

A numerical ground-water-flow model was constructed and calibrated for steady-state conditions to achieve project objectives. The numerical model used was the USGS modular three-dimensional, finite-difference ground-water-flow model (MODFLOW) developed by McDonald and Harbaugh (1988). The model was calibrated using water levels and stream stages measured in 52 observation, domestic, and commercial wells and at 12 stream sites, respectively. Two synoptic sets of low-flow streamflow measurements made on the Sauk River and Brewery Creek at 11 sites were also used to calibrate the model. VISUAL MODFLOW was used as a pre-processor to input the data, to run the MODFLOW simulations, and as a post-processor to visualize and analyze the results of the simulations (Guiguer and Franz, 1999).

The particle-tracking post-processing package MODPATH (Pollock, 1989) was used to compute groundwater flow path lines based on output from the calibrated steady-state simulation obtained with MODFLOW. In addition to three-dimensional path lines, MODPATH computes the position of particles at specified points in time and the total time-of-travel for each particle. Particle tracking was used to determine the contributing area of ground-water flow to watersupply wells and to delineate the 10 -, 20 -, and 30-year time-of-travel zones to the wells.

\section{Acknowledgments}

The author is grateful to landowners who allowed the installation of observation wells on their property and to well owners who permitted measurement of water levels in their wells. The author is also grateful to Gail Haglund of the Minnesota Department of Health, Chuck Regan of the Minnesota Pollution Control Agency, Verena Weber and Ray Koppy of the City of Cold Spring, and Benjamin Bertsch of the University of Minnesota, Duluth for providing information and assistance during the study. Thanks also are given to employees of the U.S. Geological Survey in Minnesota for their assistance with this study, particularly Michael Menheer, Christopher Sanocki, and Robert Borgstede.

\section{HYDROGEOLOGIC SETTING}

\section{Geologic Deposits}

Precambrian igneous and metamorphic rocks underlie the glacial deposits in the study area (Helgesen and others, 1975). Sedimentary rocks of Late Cretaceous age once extended across most of the area (Meyer and Swanson, 1996). Today remnants of these strata less than $25 \mathrm{ft}$ thick, consisting chiefly of soft shale, claystone, and silty fine sandstone, overlie the Precambrian rocks in some areas (fig. 2).

Surficial deposits in the Cold Spring area (fig. 2) consist mainly of late-Wisconsin glacial till and outwash sands and gravels associated with the Des Moines and Superior lobes (Meyer and Knaeble, 1995; Meyer and Swanson, 1996). Outwash sands and gravels from the Des Moines lobe fill most of the Sauk River Valley. Outcrops of igneous and metamorphic rocks, marl, peat, till, and alluvium also are present in the Sauk River Valley.

The distribution of Quaternary deposits is represented in figure 3. The glacial deposits in the uplands are composed of impermeable till, but have randomly distributed buried sand and gravel lenses throughout. Where the deposits are thinner in the bedrock valley of the Sauk River, continuous surficial alluvial deposits of highly permeable sand and gravel are present. The glacial deposits here were eroded by the Sauk River, with subsequent deposition of alluvium.

The Quaternary deposits in the study area include: (1) till with few, if any, buried sand and gravel lenses (fig. 3, zone A), (2) complex till and ice-contact stratified deposits that may include surficial or buried sand, sand and gravel lenses, or both (fig. 3, zones B and C), and (3) thick surficial sand and gravel outwash deposits (fig. 3 , zones $\mathrm{D}$ and $\mathrm{E}$ ). The glacial deposits become thicker with distance from the Sauk River (Setterholm, 1995), which is incised into the glacial deposits and down to the Precambrian bedrock in some reaches. Glacial deposits with thicknesses of as much as $50 \mathrm{ft}$ are present along the river, whereas thicknesses of as much as $250 \mathrm{ft}$ occur in the uplands northwest and southwest of Cold Spring.

\section{Hydrogeologic Units}

The areal extent of the surficial aquifer underlying the uplands in the north-central part of the study area is hereinafter termed the upland surficial aquifer (fig. 4). The eastern part of upland surficial aquifer includes the areas of Superior lobe ice contact ice contact deposits, which comprise the sand and gravel area of the aquifer. The western part of the aquifer consists of predominantly sandy Superior lobe till, with isolated surficial sand 


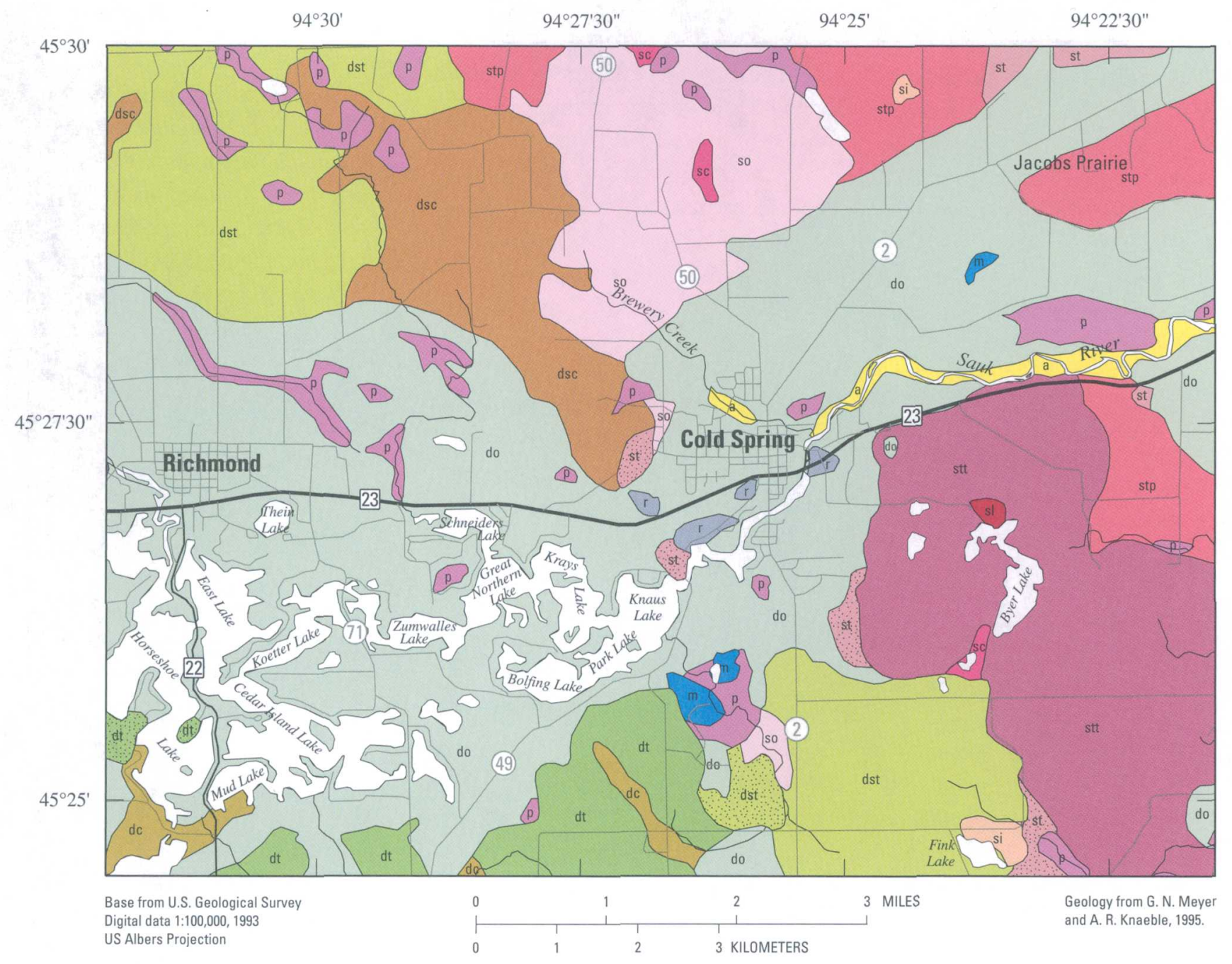

EXPLANATION

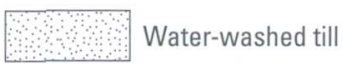

POSTGLACIAL DEPOSITS

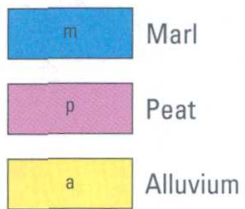

MISSISSIPPI RIVER TERRACE DEPOSITS

do Outwash deposits

\begin{tabular}{|c|c|}
\hline$d c$ & Complex of till, sand and gravel \\
\hline $\mathrm{dt}$ & Till \\
\hline dst & Till over Superior lobe deposits \\
\hline dsc & $\begin{array}{l}\text { Complex of till and Superior lobe ice-contact } \\
\text { or outwash deposits }\end{array}$ \\
\hline & SITS ASSOCIATED WITH THE SUPERIOR LOBE \\
\hline s! & Lake sand \\
\hline so & Outwash deposits \\
\hline
\end{tabular}

si Ice-contact stratified deposits

sc Complex of till, sand and gravel

stp Pitted supraglacial till

st Till

stt Thrust complex

PRECAMBRIAN ROCKS

r Igneous and metamorphic rocks

Figure 2. Surficial geology in Cold Spring area, Minnesota. 


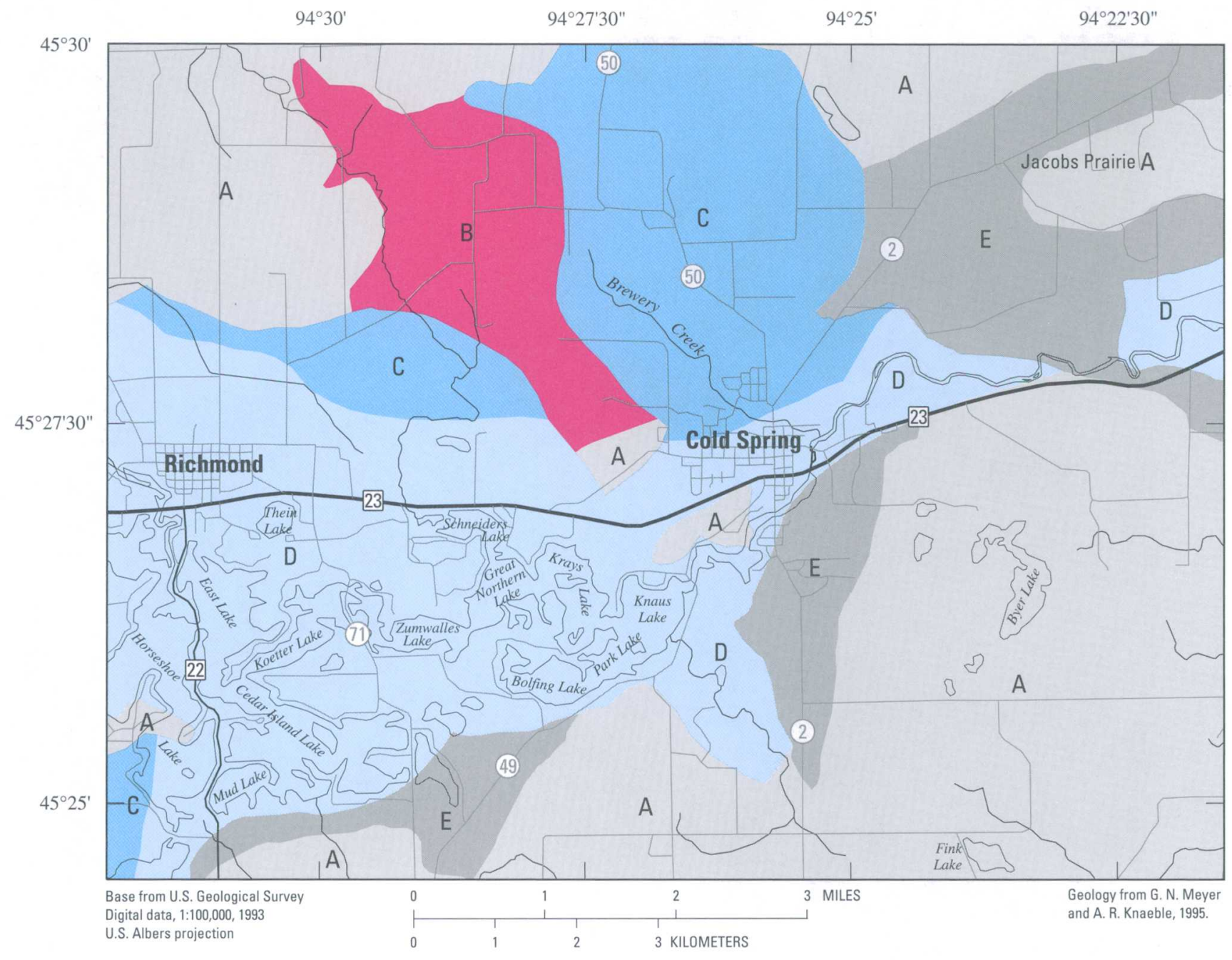

\section{EXPLANATION}

Mostly till of the Des Moines or Superior lobes. Sand beds thicker than 10 feet may be present at depth, especially where depth to bedrock exceeds 100 feet. Sand beds are discontinuous and absent in many areas.

Complex deposits include till and ice-contract stratified deposits of either or both the Des Moines lobe and Superior or Rainy lobes. Includes areas of thick surficial sand, thick sand below thin or thick till(s), and, especially in areas where depth to bedrock is less than 150 feet, thick till(s) with thin or no sand beds.

Less than 50 feet of sand or gravel over one or more beds of till or clayey lake sediment. One or more sand beds exceeding 10 feet in thickness may underlie beds of till or clayey lake sediment.
Primarily sand and gravel of the Des Moines lobe outwash over till or over bedrock; sand and gravel of Superior lobe outwash may be present in places at depth. Bedrock is near the surface in a few places. The underlying till, where present, commonly is of the Des Moines lobe in the western part of the study area and of the Superior lobe in the eastern part. In some areas the sand is seperated from bedrock by clayey lake sediment.

Greater than 50 feet of sand or gravel over mostly Superior lobe or older till, or lake sediment. Beds of sand generally less than 10 feet thick are present between the till and bedrock in places; till is very thin or absent in some areas.

Figure 3. Quaternary geology in Cold Spring area, Minnesota. 


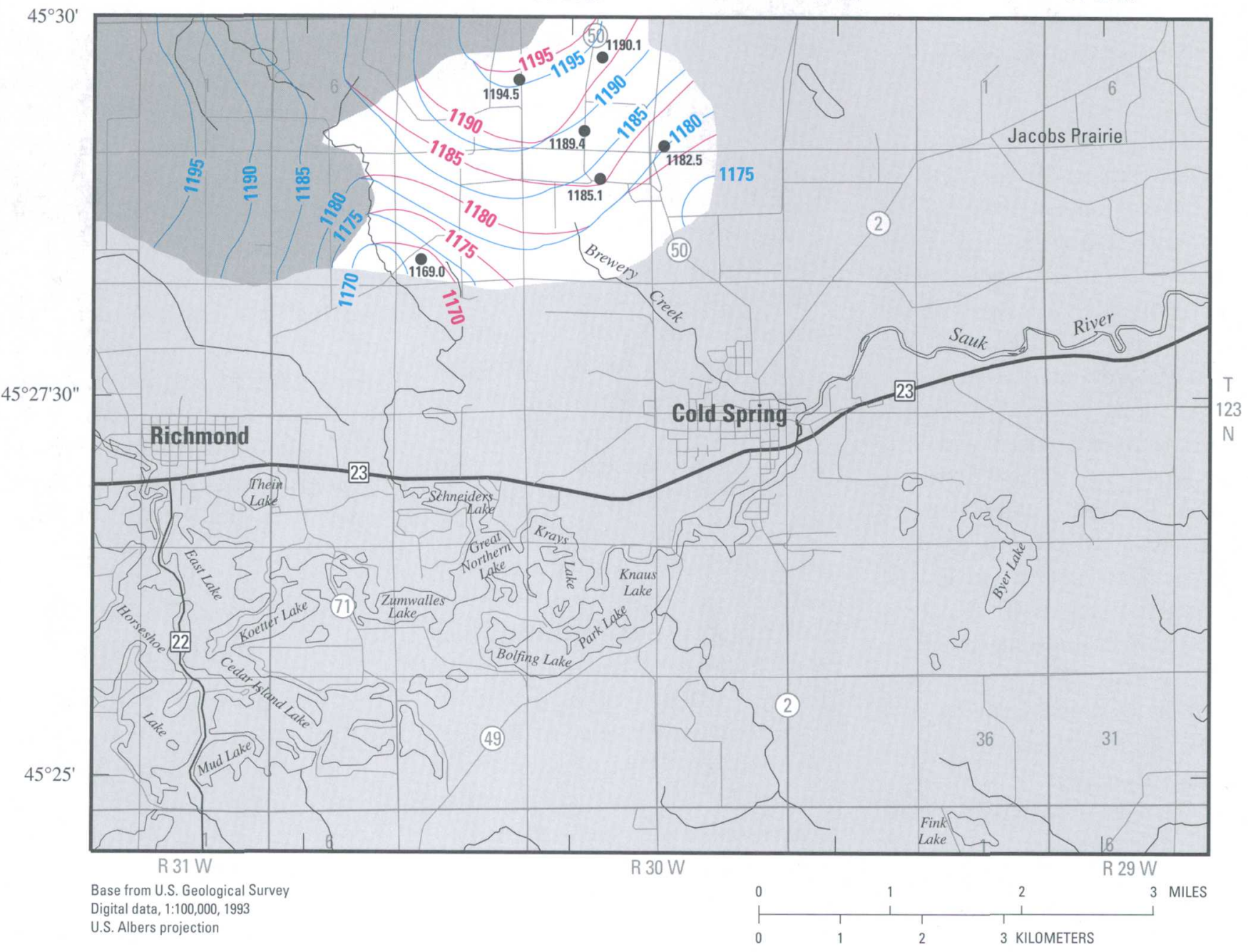

EXPLANATION

\begin{tabular}{|c|c|}
\hline & Upland surficial aquifer area of sand and gravel \\
\hline & Upland surficial aquifer area of sandy till \\
\hline & Upland surficial aquifer absent \\
\hline$-1100-$ & Simulated potentiometric contour. Interval 5 feet. Datum is sea level \\
\hline-1100 & Measured potentiometric contour. Interval 5 feet. Datum is sea level \\
\hline$\ominus^{1185.1}$ & $\begin{array}{l}\text { Domestic or commercial well. Number indicates water-level altitude, } \\
\text { in feet above sea level }\end{array}$ \\
\hline
\end{tabular}

Figure 4. Measured and simulated potentiometric surface of the upland surficial aquifer, December 1998, Cold Spring area, Minnesota. 
and gravel deposits. The upland surficial aquifer is unconfined with saturated thicknesses ranging from 6 to $37 \mathrm{ft}$.

The Sauk River Valley aquifer consists of hydraulically connected sand and gravel units in different hydrogeologic settings: (1) the generally continuous surficial unconfined unit underlying the Sauk River Valley (valley unit) and (2) buried, confined units that are overlain by till or lake clays in the upland areas. The areal extent of the aquifer (figs. 5 and 5a) includes zones B, C, D, and $\mathrm{E}$ shown in figure 3 . The valley unit is composed of outwash deposits of sand, gravelly sand, and cobbly gravel interbedded with layers of till and glacial lake sediments in some areas. South of the Sauk River in the eastern part of the study area the aquifer extends to bluffs to the south where it thins to less than $20 \mathrm{ft}$ thick. Wells dug into the side of the bluff reveal a more stratified character with layers of impermeable clay or till between the thinning sand and gravel layers. Back from the edges of the bluff away from the valley, well logs show the continuous, thick till deposit with isolated sand and gravel lenses. These lenses are probably not continuous and probably do not extend directly down into the sand and gravel in the Sauk River Valley. However, the Sauk River Valley may, to some extent, act as a drain for the uplands and receive some amount of ground-water flow from the uplands. Maximum saturated thickness of the valley unit is about $50 \mathrm{ft}$ and well yields are greater than $1,000 \mathrm{gal} / \mathrm{min}\left(2.22 \mathrm{ft}^{3} / \mathrm{s}\right)$ where sufficient saturated thickness is penetrated. Buried units of the aquifer that are in hydraulic connection with the valley unit are present in the north-central and northwestern parts of the study area. The continuity of these buried units and the degree of hydraulic con- nection between them is uncertain. Thicknesses of the buried units are generally 10 to $20 \mathrm{ft}$ in these areas.

\section{Hydraulic Properties}

Hydraulic properties of the glacial deposits are variable. Consequently, glacial deposits can be either an aquifer or a confining unit. Movement of water in the deposits is primarily intergranular. Hydraulic conductivity is the capacity of porous material to transmit water under pressure. Horizontal hydraulic conductivities for glacial aquifers typically range from $10^{1}$ to $10^{4} \mathrm{ft} / \mathrm{d}$ (Freeze and Cherry, 1979, p. 29). Lindholm (1980) reported that hydraulic conductivities of glacial deposits in central Minnesota, including Stearns County, range from $10 \mathrm{ft} / \mathrm{d}$ for clay or silt to $700 \mathrm{ft} / \mathrm{d}$ for gravel. Delin (1988) reported horizontal hydraulic conductivities ranging from 10 to $750 \mathrm{ft} / \mathrm{d}$, with average values of 125 to $180 \mathrm{ft} / \mathrm{d}$, for confined glacial sand and gravel aquifers in west-central Minnesota. A mean horizontal hydraulic conductivity value of $1.4 \times 10^{-1} \mathrm{ft} / \mathrm{d}$ was calculated for till in west-central Minnesota, based on the results from eight slug tests (Delin, 1988). The vertical hydraulic conductivity of till typically ranges from $10^{-6}$ to $1 \mathrm{ft} / \mathrm{d}$ (Freeze and Cherry, 1979, p. 29). Delin (1988) reported that the vertical hydraulic conductivity of till in west-central Minnesota, based on analysis of four aquifer tests, ranged from $8.6 \times 10^{-6}$ to $1.8 \mathrm{ft} / \mathrm{d}$, with a mean value of $4.0 \times 10^{-1} \mathrm{ft} / \mathrm{d}$. Miller (1982) reported a value of $1.8 \times 10^{-2} \mathrm{ft} / \mathrm{d}$ for the vertical hydraulic conductivity of till in western Minnesota.

Prior to this study, aquifer tests were conducted for the Sauk River Valley aquifer in the Cold Spring area at two sites. During November 1993, a 24-hour aquifer test was conducted at the Gold'n Plump Poultry Processing Plant site. A transmissivity (the product of horizontal hydraulic conductivity and saturated thickness) of $11,000 \mathrm{ft}^{2} / \mathrm{d}$ was estimated for the aquifer from the aquifer-test results, with a corresponding horizontal hydraulic conductivity of $250 \mathrm{ft} / \mathrm{d}$ (HDR Engineering, Inc., 1995). In October 1997, a 24-hour pumping and recovery aquifer test was conducted at the site of Cold Spring municipal wells CS1 and CS2. A transmissivity of $23,000 \mathrm{ft}^{2} / \mathrm{d}$ was estimated for the aquifer from the aquifer-test results, with a corresponding horizontal hydraulic conductivity of $350 \mathrm{ft} / \mathrm{d}$ (Gail Haglund, Minnesota Department of Health, written commun., 1999).

\section{Ground-water flow, sources, and discharge}

Ground water flows from areas of high hydraulic head toward areas of low hydraulic head (perpendicular to potentiometric contours). The direction of movement is related to locations of recharge to and discharge from the ground-water system. The rate of movement is related to the hydraulic conductivity of aquifer material and to the hydraulic gradient. Aquifers are less resistant to the horizontal flow of ground water than confining units because the hydraulic conductivity of aquifers is much greater than that of confining units. Flow in aquifers is predominantly horizontal, whereas flow in confining units is predominantly vertical.

Ground-water flow in the upland surficial aquifer is (1) to the south and southeast toward the margins of the aquifer, and (2) from the uplands toward an unnamed creek valley in the central part of the aquifer (fig. 4). The water table is the surface in an unconfined aquifer at which the water pressure is atmospheric and generally coincides with the potentiometric surface (fig. 4). A broad, poorly defined 


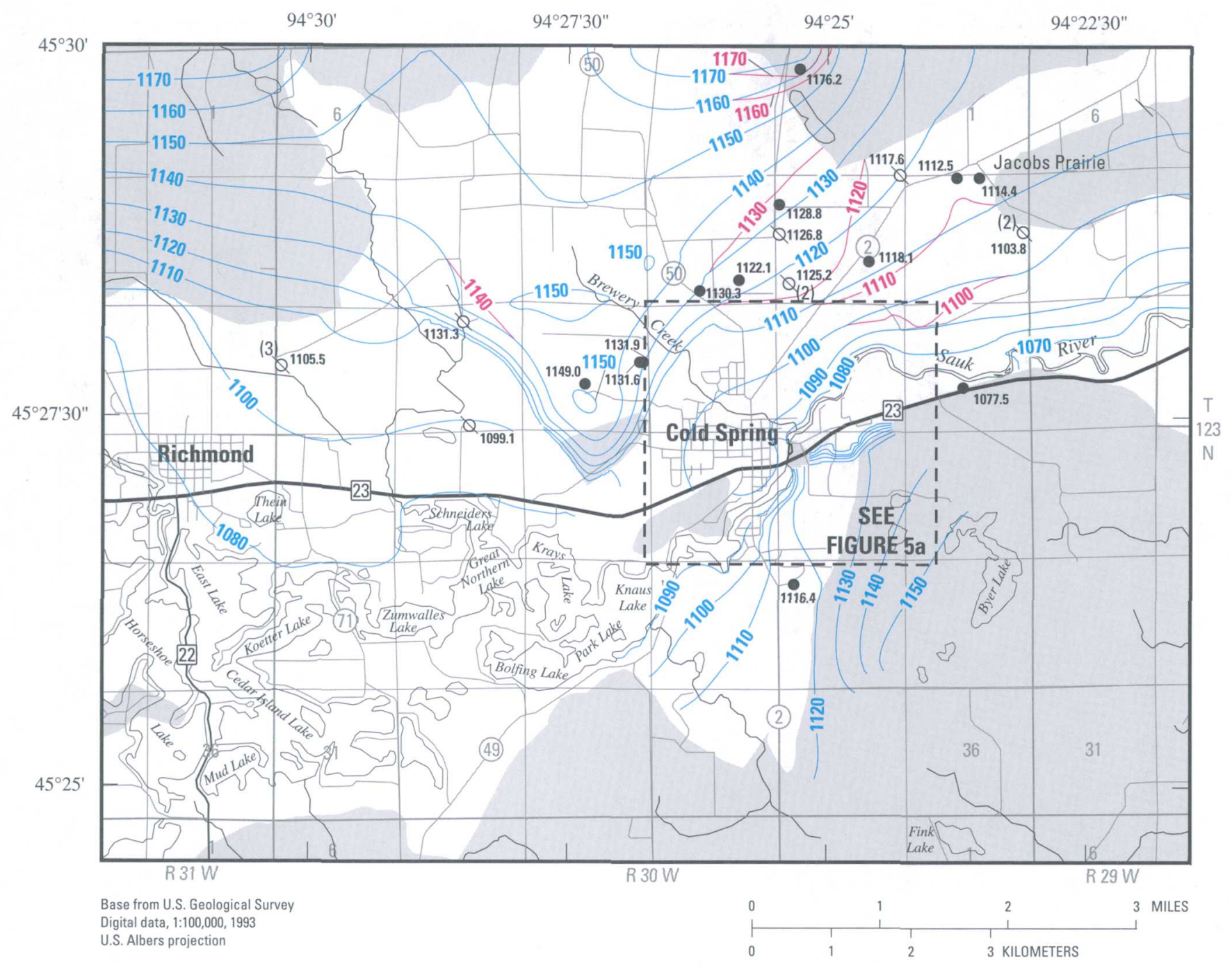

EXPLANATION

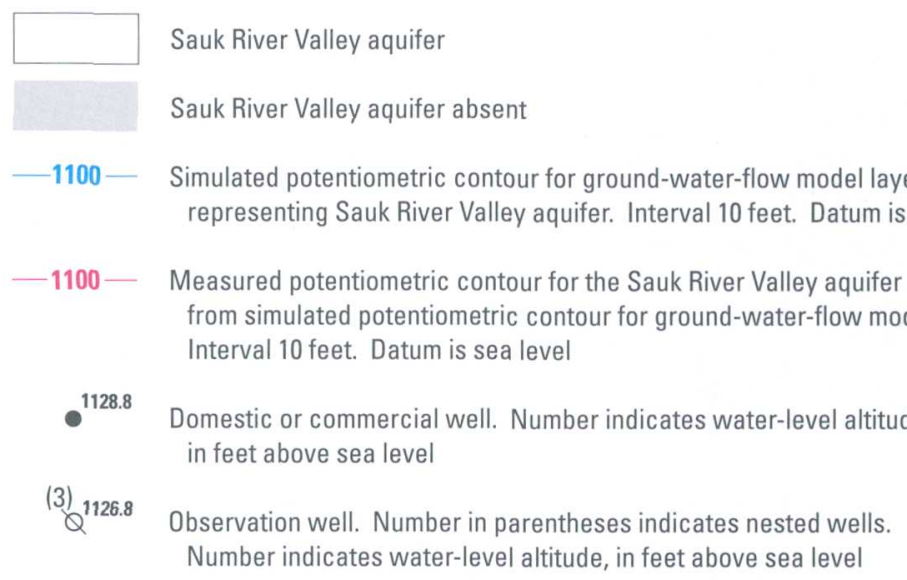

Figure 5. Measured and simulated potentiometric surface of the Sauk River Valley aquifer, December 1998, Cold Spring area, Minnesota. 


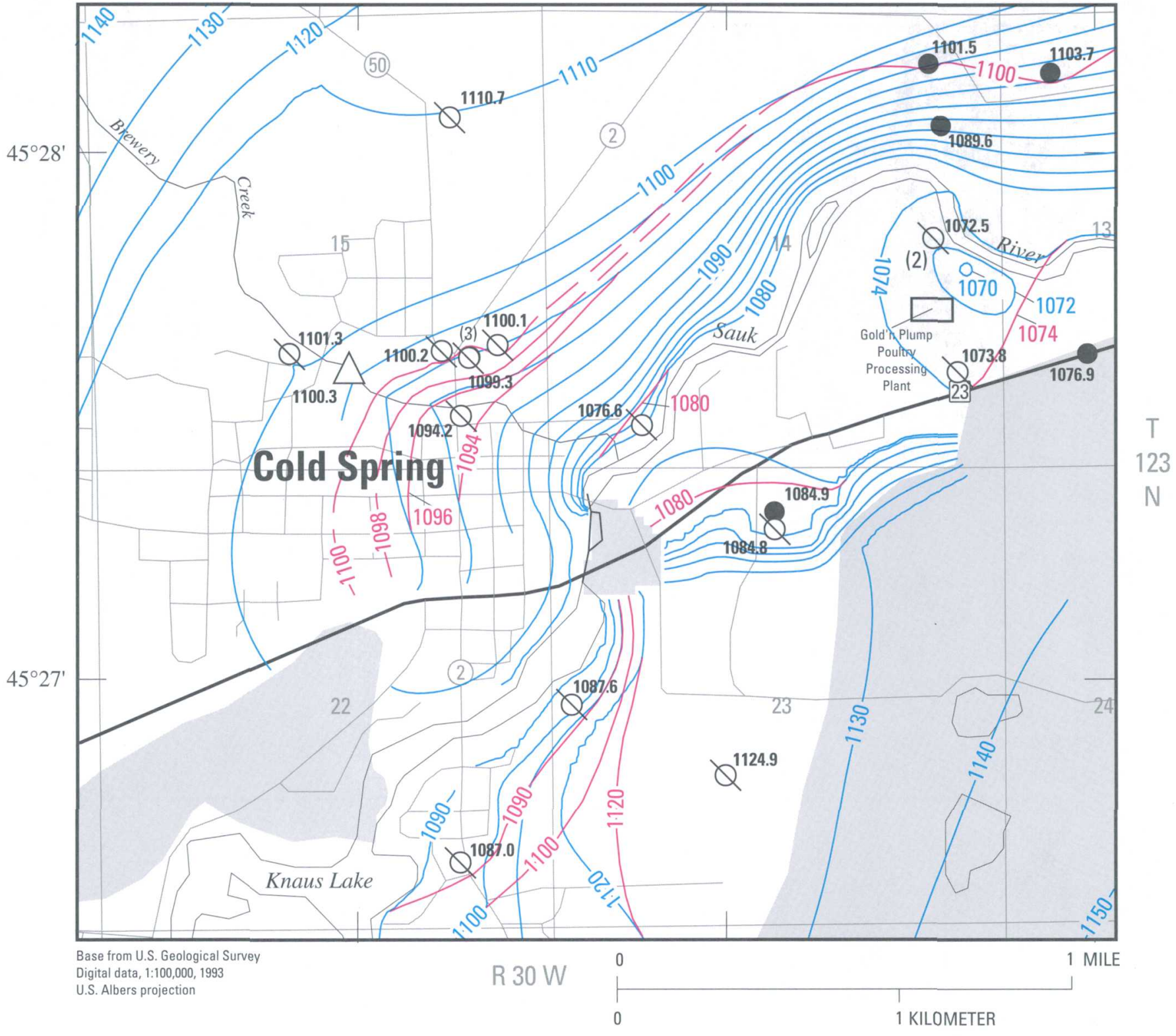

\begin{tabular}{|c|c|}
\hline & Sauk River Valley aquifer \\
\hline & Sauk River Valley aquifer absent \\
\hline$-1100-$ & $\begin{array}{l}\text { Simulated potentiometric contour for } \\
\text { ground-water-flow model layer } 3 \text {, } \\
\text { representing Sauk River Valley aquifer. } \\
\text { Interval variable. Datum is sea level }\end{array}$ \\
\hline$-1100-$ & $\begin{array}{l}\text { Measured potentiometric contour for the } \\
\text { Sauk River Valley aquifer deviates from } \\
\text { simulated potentiometric contour for } \\
\text { ground-water-flow model layer } 3 \text {. Dashed } \\
\text { where inferred. Interval variable. Datum is } \\
\text { sea level }\end{array}$ \\
\hline
\end{tabular}

EXPLANATION

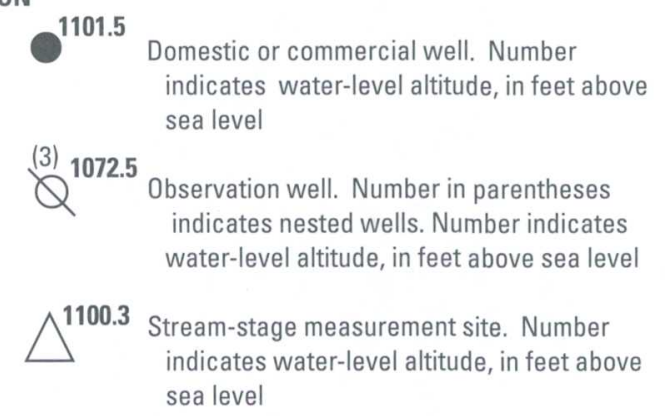

Figure 5a. Measured and simulated potentiometric surface of the Sauk River Valley aquifer, near Cold Spring and Gold'n Plump Poultry Processing Plant, December 1998, Cold Spring area, Minnesota. 
regional potentiometric high occurs in the water-table surface in the vicinity of Big Fish Lake located about 1 mile north of the study area. Ground water flows to the south, east, and west away from this high (fig. 4). Sources of water to the upland surficial aquifer are (1) infiltration of precipitation to the saturated zone (areal recharge) and (2) some ground-water flow through the northern boundary due to the potentiometric high located north of the study area. Discharge from the aquifer is by (1) withdrawals from domestic and irrigation wells, (2) ground-water evapotranspiration in areas where the water table is within about $5 \mathrm{ft}$ of land surface (approximate depth of root zones), and (3) leakage downward through a till and clay confining unit to the buried units of the Sauk River Valley aquifer. Hydraulic heads in the upland surficial aquifer are about 30 to $40 \mathrm{ft}$ higher than in the underlying Sauk River Valley aquifer. Locally, ground water also discharges to small streams and lakes.

Ground-water flow in the Sauk River Valley aquifer is from upland areas toward the Sauk River and the connected chain of lakes (fig. 5). Near the west-central boundary of the study area, ground-water flow is from east to west toward the Sauk River, located just west of the boundary. The flow of ground water is restricted and altered in some areas due to the presence of bedrock and low permeability till. The aquifer is under unconfined conditions throughout most of its areal extent, but is under confined conditions where it is buried by till and clay in the northwestern part of the study area. The mound in the potentiometric surface of the aquifer west of Cold Spring (fig. 5) is due to the presence of thick till and clay overlying the buried aquifer and the transition from confined to unconfined conditions.
The aquifer includes surficial sand and gravel deposits in the north-central part of the study area that are in hydraulic connection with the sand and gravel deposits at lower altitudes closer to the Sauk River. These higher-altitude sand and gravel deposits continue to the north and allow ground-water flow to enter the study area from the north. As for the watertable surface, a broad, poorly defined regional potentiometric high occurs in the vicinity of Big Fish Lake located about 1 mile north of the study area. In general, the depth to the water table in the Sauk River Valley increases with increasing distance from the Sauk River. The water table near the river is about $5 \mathrm{ft}$ below land surface and north of Cold Spring near municipal well CS4 is about $40 \mathrm{ft}$ below land surface.

Sources of water to the Sauk River Valley aquifer in the study area are (1) infiltration of precipitation to the saturated zone (areal recharge) in areas where the aquifer is unconfined, (2) ground-water flow through the northern boundary, (3) leakage of water through overlying till and clay for buried units of the aquifer, and (4) probably ground-water flow from the undifferentiated glacial deposits in the southeastern part of the study area. Discharge from the aquifer is (1) by withdrawals from wells, (2) by ground-water evapotranspiration in areas where the water table is within about 5-10 ft of land surface (approximate depth of root zones), and (3) to the Sauk River, the chain of lakes, and Brewery Creek. Locally, ground water also discharges to smaller streams and lakes. Ground-water withdrawals and stream-aquifer leakage are discussed further in the following sections.

Water levels in the Sauk River Valley aquifer fluctuate in response to seasonal variations in recharge and discharge. Ground-water levels com- monly rise in spring, when areal recharge is generally greatest because of snowmelt, spring rain, and minimal evapotranspiration losses. Conversely, ground-water levels generally decline in summer because discharge by evapotranspiration, ground-water withdrawals by wells, and discharge to streams and lakes exceed recharge. Net recharge to the aquifer also occurs in the fall most years, due to rainfall and low evapotranspiration losses. Ground-water recharge rates to the aquifer for 1999 were estimated from monthly water-level measurements for the 21 observation wells installed for this study and the 7 existing observation wells. Recharge rates were estimated using the method of hydrograph analysis described by Rasmussen and Andreasen (1959). The method assumes that all waterlevel rises in a well result from areal recharge. The estimated ground-water recharge rates to the aquifer ranged from 5.3 to $8.6 \mathrm{in./yr}$, with an average value of $7.0 \mathrm{in} . / \mathrm{yr}$.

\section{Ground-Water Withdrawals}

Ground water provides the primary source of drinking water for the Cold Spring area. There are about 25 public water-supply wells and 200300 private water-supply wells in the study area (Minnesota Department of Health, 1999). All of the public supply wells are screened in the valley unit of the Sauk River Valley aquifer. Many of the private water-supply wells in the northwestern part of the study area are screened in buried units of the aquifer. A few private watersupply wells are open to Precambrian bedrock in areas where glacial aquifers are lacking and the bedrock is within about $100 \mathrm{ft}$ of land surface. Ground water is also the primary source of water for irrigation, golf course, and landscape wells in the study area. The total pumpage in the study area during 1998 from 15 irriga- 
tion wells was 204.8 million gallons (27.37 million $\left.\mathrm{ft}^{3}\right)$. An additional 56.9 million gallons ( 7.60 million $\left.\mathrm{ft}^{3}\right)$ was withdrawn during 1998 from five golf course and landscape wells.

During June 1995, the city of Cold Spring initiated the development of a WHP plan. During September 1997 , the city invited local water suppliers to form a partnership to develop a joint WHP management plan. The resulting public-private partnership, consisting of six public and private water suppliers, began to develop a single WHP management plan to address and manage land-use activities for the combined areas. A total of 18 wells, screened in the Sauk River Valley aquifer comprise the well fields of the six water suppliers.

The City of Cold Spring currently has four municipal wells and is planning to install a fifth well near municipal well CS4 (Ray Koppy, City of Cold Spring, oral commun., 1999). Three of the wells are located within the city limits (Cold Spring municipal wells CS1, CS2, and CS3) and the fourth is located in T123N,R30W, section 11 about 1 mile north of the City (Cold Spring municipal well CS4) (figs. 1 and 1a). The wells are screened at depths ranging from 51 to $100 \mathrm{ft}$. During August 1996, nitrate levels exceeded $10 \mathrm{mg} / \mathrm{L}$ as $\mathrm{N}$ in water sampled from Cold Spring municipal well CS1 (Minnesota Department of Health, 1999). The well has not been used for public supply since that time. Withdrawals of water from Cold Spring municipal well CS4 began during November 1999. The total pumpage for the Cold Spring municipal wells during 1998 was 140.8 million gallons (18.82 million $\mathrm{ft}^{3}$ ) (Verena Weber, City of Cold Spring, written commun., 1999).

The Gold'n Plump Poultry Processing Plant is located about 1 mile east of Cold Spring (fig. 1a) and currently operates six production wells within their property. The well field is almost parallel to the Sauk River at an average distance of $300 \mathrm{ft}$ from the river. The upland bluffs south of the plant site are about 2,000 ft away from the well field. The wells are screened at depths ranging from 37 to $47 \mathrm{ft}$. The total pumpage for the Gold'n Plump Poultry Processing Plant wells during 1998 was 281.6 million gallons (37.64 million $\mathrm{ft}^{3}$ ) (Clay Watson, Gold 'n Plump Poultry, written commun., 1999).

The Gluek Brewing Company (fig.1a) and Cold Spring Granite Company (fig. 1) utilize ground water in their product processing operations. The Gluek Brewery has two wells located within $500 \mathrm{ft}$ of Cold Spring municipal wells CS1 and CS2. The wells pumped 10.0 million gallons (1.33 million $\mathrm{ft}^{3}$ ) of water during 1998 (Mike Kneip, Gluek Brewing Company, written commun., 1999). Cold Spring Granite Company also has two wells within their property located about 1.5 miles west of Cold Spring. The wells pumped an estimated 1.0 million gallons $(0.13$ million $\left.\mathrm{ft}^{3}\right)$ of water during 1998 (reported pumpage amounts were not available) (Gail Haglund, Minnesota Department of Health, written commun., 1999). The two remaining members of the partnership are Town's Edge Mobile Home Park, located about 0.5 mile southeast of Cold Spring, and Cold Spring Alano Society, located about 1 mile northeast of the city (fig. 1a). Town's Edge Mobile Home Park withdrew 8.7 million gallons (1.16 million $\mathrm{ft}^{3}$ ) of water during 1998 from two wells screened at depths of 60 and $97 \mathrm{ft}$ (Gene Hesse, Town's Edge Homes Incorporated, written commun., 1999). The Cold Spring Alano Society withdrew an estimated 1.0 million gallons $(0.13$ million $\mathrm{ft}^{3}$ ) of water during 1998 from two wells (reported pumpage amounts were not available) (Gail Haglund, Minnesota Department of Health, written commun., 1999).

\section{Stream-Aquifer Leakage}

Stream-aquifer leakage refers to the movement of water between a stream and the underlying aquifer. Leakage may occur from the aquifer to the stream, resulting in an increase in streamflow (gaining stream or reach), or leakage may occur from the stream to the aquifer, resulting in a decrease in streamflow (losing stream or reach). Streams may be gaining water in some reaches and losing water in others. The rate of streamaquifer leakage depends on the: (1) thickness of the streambed material, (2) vertical hydraulic conductivity of the streambed material, (3) hydraulic conductivity of the aquifer near the stream, and (4) hydraulic-head differences between the aquifer and the stream. Ground water generally represents most of streamflow during periods of low flow rates. Ground-water leakage to streams in the Cold Spring area is generally greater than leakage from streams to the underlying aquifer, and the streams are therefore gaining streams overall.

Synoptic sets of low-flow measurements were made to determine gaining and losing reaches of the Sauk River and Brewery Creek and to quantify streamflow gains and losses. Streamflow measurements were made at nine sites on the Sauk River and at three sites on Brewery Creek during October 1998 and August 1999 (table 1; figs. 1a and 1). The measurements indicated net gains of 44.8 (SW5SW9) and 25.8 (SW4 -SW9) $\mathrm{ft}^{3} / \mathrm{s}$ for the Sauk River from Cold Spring to Rockville, located about 1 mile east of the study area, during October 1998 and August 1999, respectively. The net gains were 15 and 13 percent of 


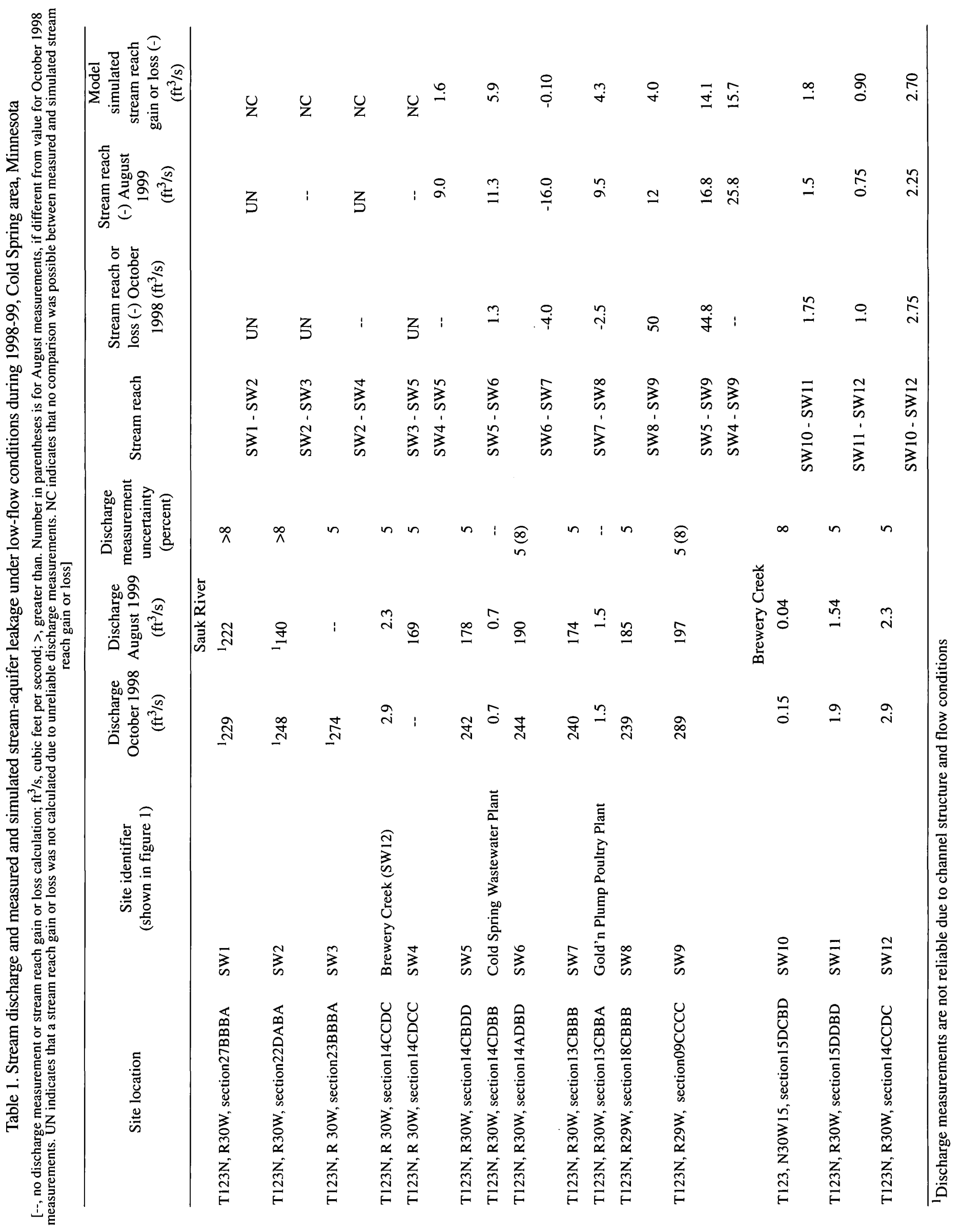


the streamflow at Rockville during October 1998 and August 1999, respectively. In general, the Sauk River probably is a gaining stream in all reaches, except for the reach adjacent to the Gold'n Plump Poultry Processing Plant well field. Groundwater withdrawals from the well field result in declines in the potentiometric surface of the aquifer near the supply wells (fig. 5a), thereby inducing infiltration of water from the Sauk River to the underlying aquifer. Groundwater withdrawals from the well field also result in intercepted subsurface flow, ground-water flow en route to the stream channel that would have eventually discharged into the stream, but is intercepted by pumped wells. The measured streamflow losses (SW6-SW7; 4.0 and $16.0 \mathrm{ft}^{3} / \mathrm{s}$ ) (table 1) were appreciably greater than the volume of water being pumped by the Gold'n Plump Poultry Processing Plant supply wells $\left(1.2 \mathrm{ft}^{3} / \mathrm{s}\right)$. The differences may be attributed to measurement error in the low-flow measurements. Streamflow losses of similar magnitude to the pumping rates would have been less than the 5 to 8 percent uncertainty in the streamflow measurements.

Streamflow gains and losses for the Sauk River were less than the accuracy of streamflow measurements (5-8 percent) in many of the reaches during the low-flow measurements (table 1). Gaining and losing reaches were somewhat inconsistent between low-flow measurement periods as a result of gains and losses being near or below the measurement accuracy and due to variations in flow conditions. The measurements during October 1998 indicated a large loss in streamflow for the reach between SW3 and SW5. However, during the August 1999 measurements with lower streamflows and stream stages, stream channel conditions at SW3 were such that an accurate streamflow measurement was not possible.

Assuming that stream channel conditions in 1998 were the same as they were in 1999, the anomalous large loss for the reach indicated by the October 1998 measurements is probably incorrect, especially because there are no known surface-water diversions in the reach or other explanation for a large loss in streamflow to occur. The streamflow measurements for SW1 and SW2 are also not considered to be reliable because of the comparatively large estimated measurement errors of greater than 8 percent due to very low flow velocities. SW1 and SW2 are in the reach of the Sauk River between the chain of lakes and a natural waterfall with a drop in river stage of about $8 \mathrm{ft}$. The river is wider and has much slower flow velocities upstream of the waterfall than downstream. The streamflow gains in the river reaches downstream from SW4, other than the reach adjacent to the Gold'n Plump Poultry Processing Plant well field (SW6-SW7), during August 1999 ranged from 9.0 to $12 \mathrm{ft}^{3} / \mathrm{s}$ (table 1). The measured streamflow gain from SW5 to SW9 during August $1999\left(16.8 \mathrm{ft}^{3} / \mathrm{s}\right)$ was much less than in October 1998 $\left(44.8 \mathrm{ft}^{3} / \mathrm{s}\right)$ and is probably more representative of low-flow conditions.

Brewery Creek is a gaining stream from SW10 to its confluence with the Sauk River (table 1; figs. 1a and 1). The creek flows through a wetland area upstream from SW 10 and the creek channel is poorly defined, precluding accurate streamflow measurements. The measured gains in streamflow between SW10 and SW12, located about 100 yards above the creek's confluence with the Sauk River, were 2.75 and $2.25 \mathrm{ft}^{3} / \mathrm{s}$ during October 1998 and August 1999 , respectively.

\section{SIMULATION OF GROUND- WATER FLOW}

A conceptual model, a qualitative description of the known characteristics and functioning of the groundwater system, was formulated from knowledge of the hydrogeologic setting, aquifer characteristics, distribution and amount of recharge and discharge, and aquifer boundaries. A numerical model of ground-water flow was constructed based on the conceptual model of the system. The model was calibrated for steady-state conditions. Steady-state represents equilibrium, or average conditions whereby hydraulic heads and the volume of water in storage do not change substantially with time. Average conditions were used for WHP planning purposes.

\section{Numerical Model Description}

The study area was subdivided into rectangular finite-difference grid cells within which the properties of the hydrogeologic unit represented are assumed to be uniform. The center of a grid cell is referred to as a node and represents the location for which the hydraulic head is computed by the model. The variably-spaced finite-difference grid used to spatially discretize the model area has 229 rows and 257 columns (fig. 6). Notation of the form $(11,24)$, where the first number in parentheses indicates the row and the second number indicates the column, is used to refer to the location of an individual cell within the grid. The dimensions of the grid cells range from 50 to $400 \mathrm{ft}$ along rows and columns. One criterion used to determine the minimum size of grid cells was to have only one water-supply well per grid cell where possible. The smallest cells ( $50 \mathrm{ft}$ by $50 \mathrm{ft}$ ) are in the vicinity of the Gold'n Plump Poultry Processing Plant site, where the supply wells 
are closest together. Small cells actually extend across the model grid, although they are shown only along the edges of the grid in figure 6 , for clarity. Hydraulic properties assigned to the cells towards the model area boundaries are averaged over larger areas than for cells near the well fields. The area modeled was extended away from the supply wells sufficient distances to be located beyond the cones of depression caused by current or projected ground-water withdrawal rates.

The ground-water system in the model area was subdivided vertically into four layers, corresponding to generally horizontal hydrogeologic units. The altitudes of the layer tops and layer bottoms were specified for each model cell for the four layers. The thickness associated with a cell representing a hydrogeologic unit is incorporated in the transmissivity term for the cell. Simulation of leakage of water between model layers is dependent on the thicknesses and vertical hydraulic conductivities between adjacent layers. A more detailed discussion of leakage of water between model layers can be found in McDonald and Harbaugh (1988).

The hydrogeologic units represented in the ground-water-flow model are, in descending order (figs. 7-10): (1) the upland surficial aquifer (layer 1), (2) the confining unit underlying the upland surficial aquifer (layer 2), (3) the valley and buried units of the Sauk River Valley aquifer and laterally adjacent clay and till above an altitude of 1,035 ft (layer 3), and (4) the deeply buried part of the Sauk River Valley aquifer below an altitude of 1,035 ft (deeply buried unit) (layer 4). In the upland areas in the northwestern part of the study area where the buried units of the Sauk River Valley aquifer are present, cells in model layers 3 and 4 were assigned the hydraulic properties of the aquifer.

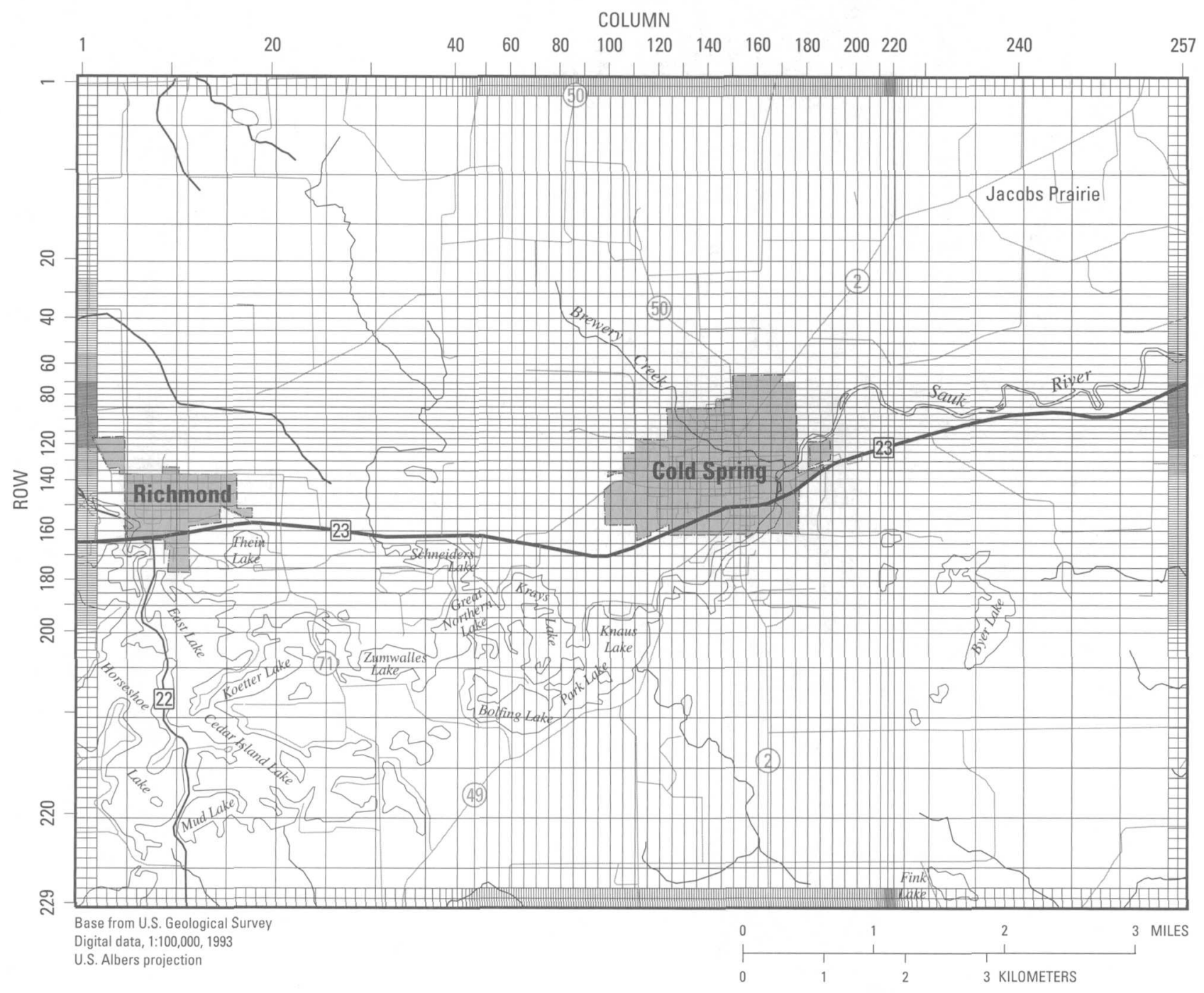

Figure 6. Grid for finite-difference ground-water-flow model, Cold Spring area, Minnesota. 
Where the buried units are absent, cells in model layers 3 and 4 were assigned the hydraulic properties of clay and till.

The transmissivities associated with the model cells representing the upland surficial aquifer (layer 1) vary as the saturated thicknesses vary. The transmissivities assigned to the model cells representing the confining unit underlying the upland surficial aquifer (layer 2) and the deeply buried unit of Sauk River Valley aquifer (layer 4) are constant in time. The Sauk River Valley aquifer (layer 3) is unconfined and confined in different parts of the modeled area. The transmissivities of cells representing the aquifer, therefore, vary where the aquifer is under unconfined conditions and are con- stant in time where it is under confined conditions. The aquifer is under unconfined conditions in the Sauk River Valley and is under confined conditions in the upland areas in the northwestern part of the study area

Ideally, all model boundaries should be located at the physical limits of the aquifer system or at other hydrologic boundaries, such as a

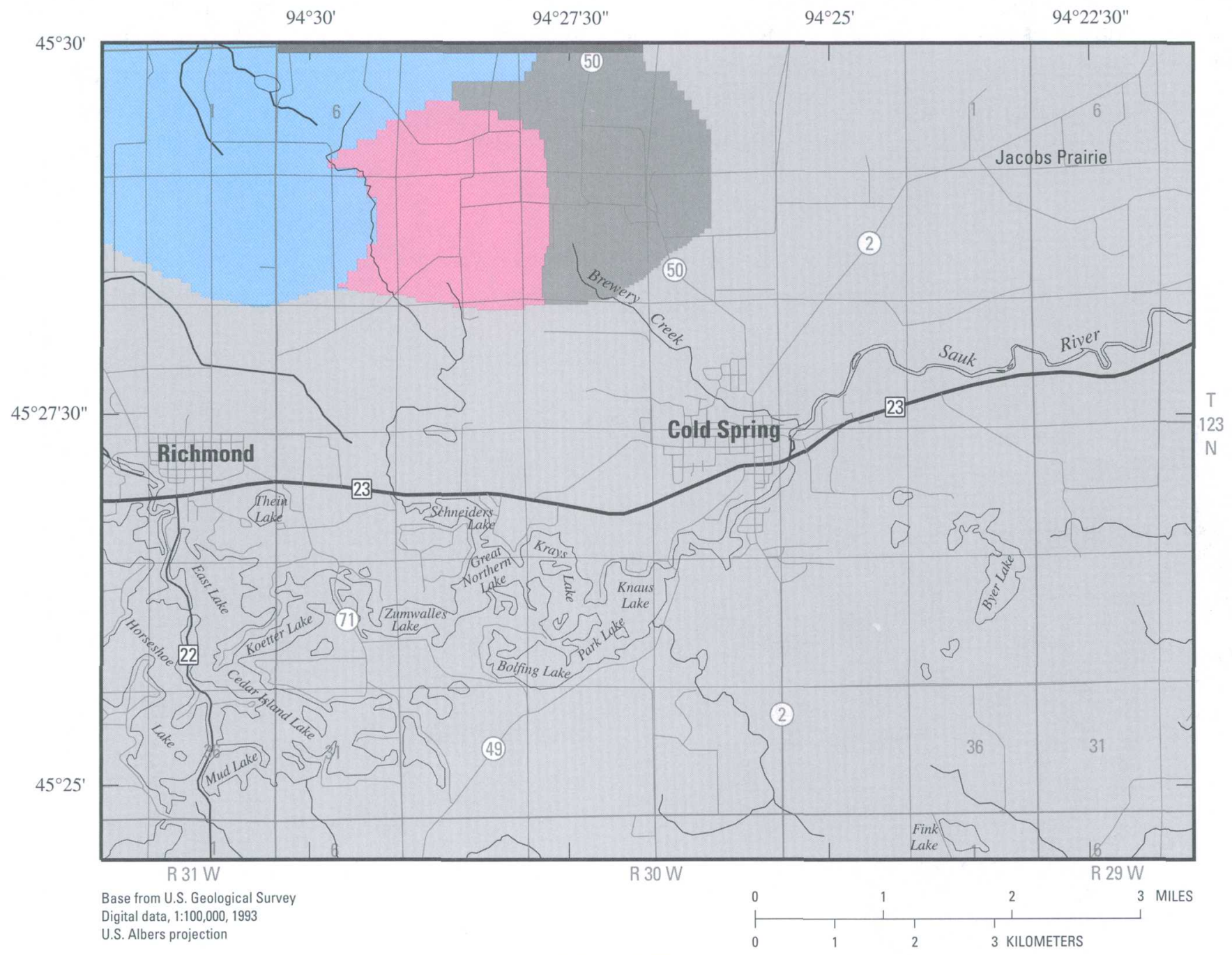

EXPLANATION

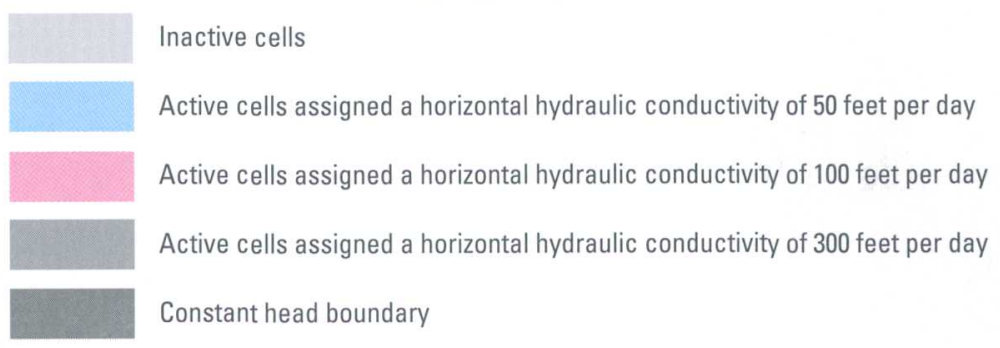

Figure 7. Extent, boundary conditions, and calibrated horizontal hydraulic conductivity zones for ground-water-flow model layer 1 , Cold Spring area, Minnesota. 
major river. Practical considerations, such as limitations concerning the size of the area modeled may necessitate the use of arbitrarily imposed model boundaries where the natural hydrologic boundaries lie outside the model area. The northern boundaries for layers 1 and 3, and the northwestern boundary for layer 4 , are arbitrarily imposed boundaries placed at the northern and northwestern township line of Wakefield Township (T123N, R30W), respectively.

The southern and eastern boundaries for layer 1 (upland surficial aquifer), the southeastern and parts of the south-central boundary for layer 3 (Sauk River Valley aquifer), and all but the northwestern and western boundaries for layer 4 (deeply buried unit of the Sauk River Valley aquifer) are located at the physical limits of the hydrogeologic units; therefore, no-flow boundaries were used. The northwestern and eastern boundaries for layer 3 and the western boundary for layer 4 are no-flow boundaries because the potentiometric surfaces for the aquifers indicate that groundwater flow near these boundaries is predominantly north to south (parallel to the boundaries) toward the Sauk

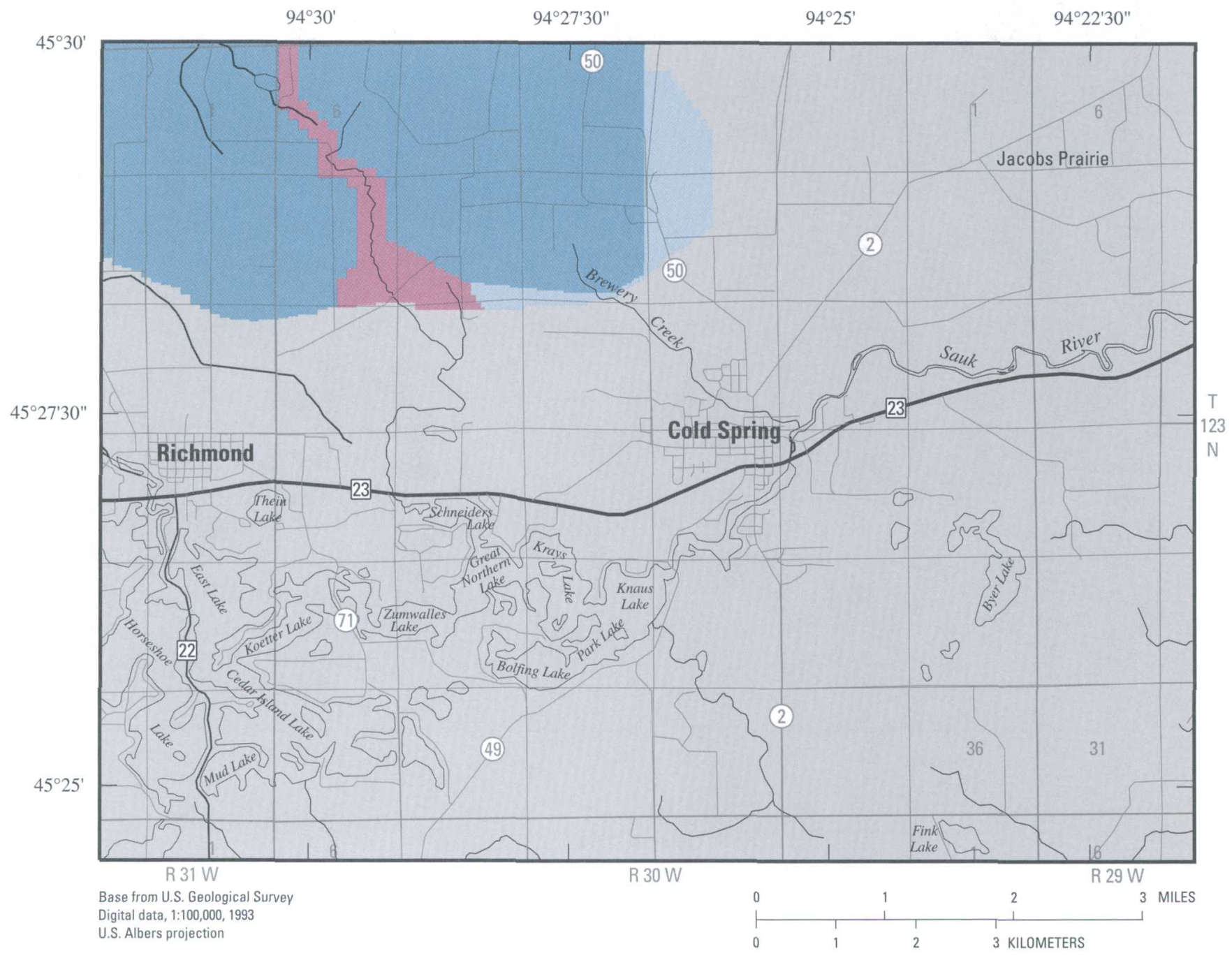

EXPLANATION

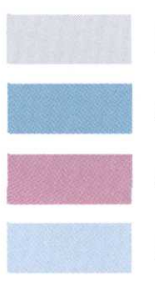

Inactive cells

Active cells assigned a vertical hydraulic conductivity of 0.00005 of a foot per day

Active cells assigned a vertical hydraulic conductivity of 0.005 of a foot per day

Active cells assigned a vertical hydraulic conductivity of 0.01 of a foot per day

Figure 8. Extent, boundary conditions, and calibrated vertical hydraulic conductivity zones for ground-water-flow model layer 2, Cold Spring area, Minnesota. 
River and the chain of lakes. The potentiometric surface of surficial aquifers near the south-central boundary for layer 3 indicates that groundwater flow near this boundary is also predominantly parallel to the boundary (east-west, from potentiometric surface highs toward an unnamed creek) and a no-flow boundary was used. The boundaries for layer 2, representing the confining unit, were imposed to coincide with the boundaries for layer 1. Because groundwater flow in confining units is pre- dominantly vertical, no-flow boundary conditions were used for all boundaries for layer 2 . The western boundary for layer 1 , portions of the northern boundaries for layers 1 and 3 , portions of the southeastern and south-central boundaries for layer 3 ,

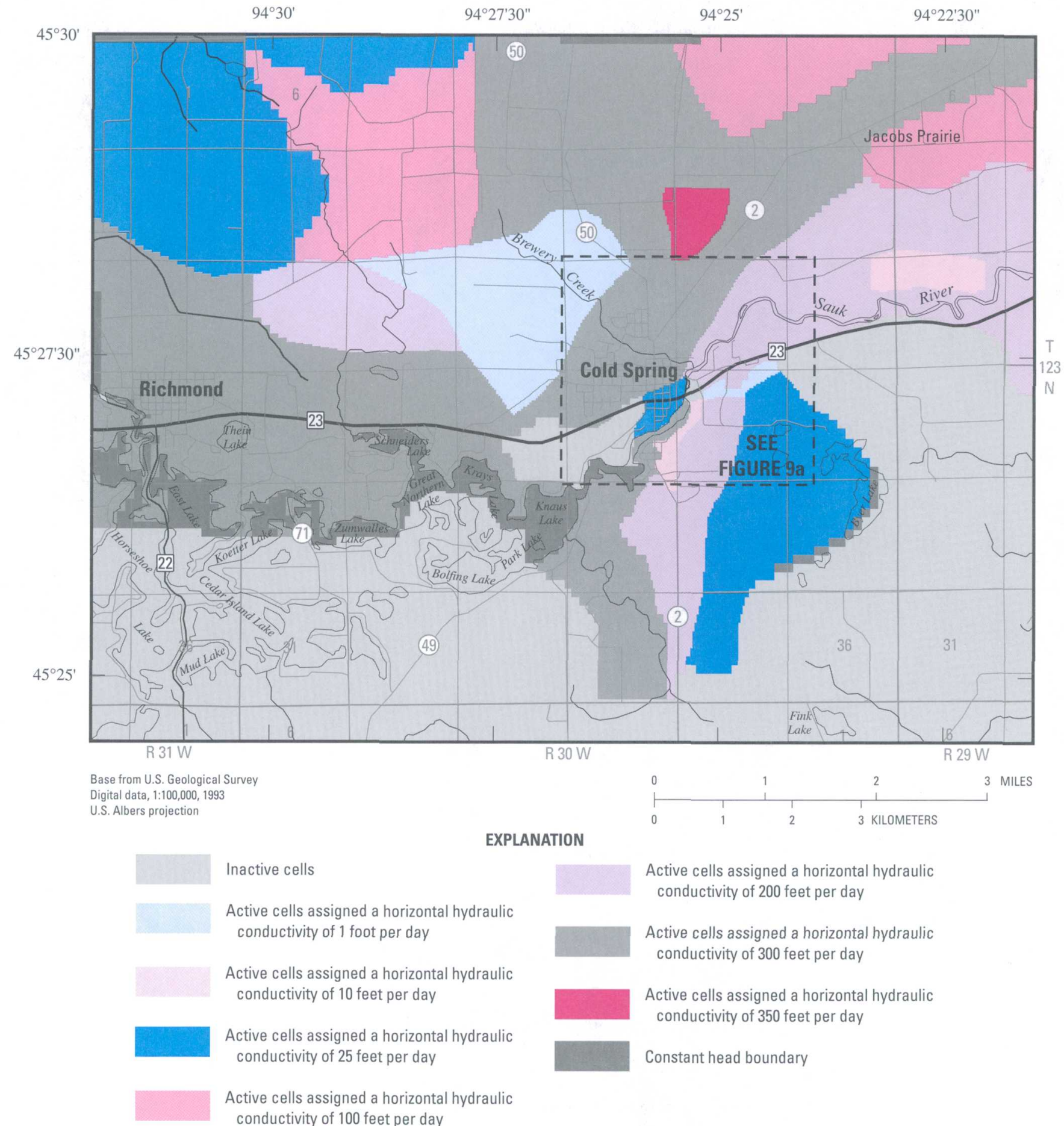

Figure 9. Extent, boundary conditions, and calibrated horizontal hydraulic conductivity zones for ground-water-flow model layer 3 , Cold Spring area, Minnesota. 


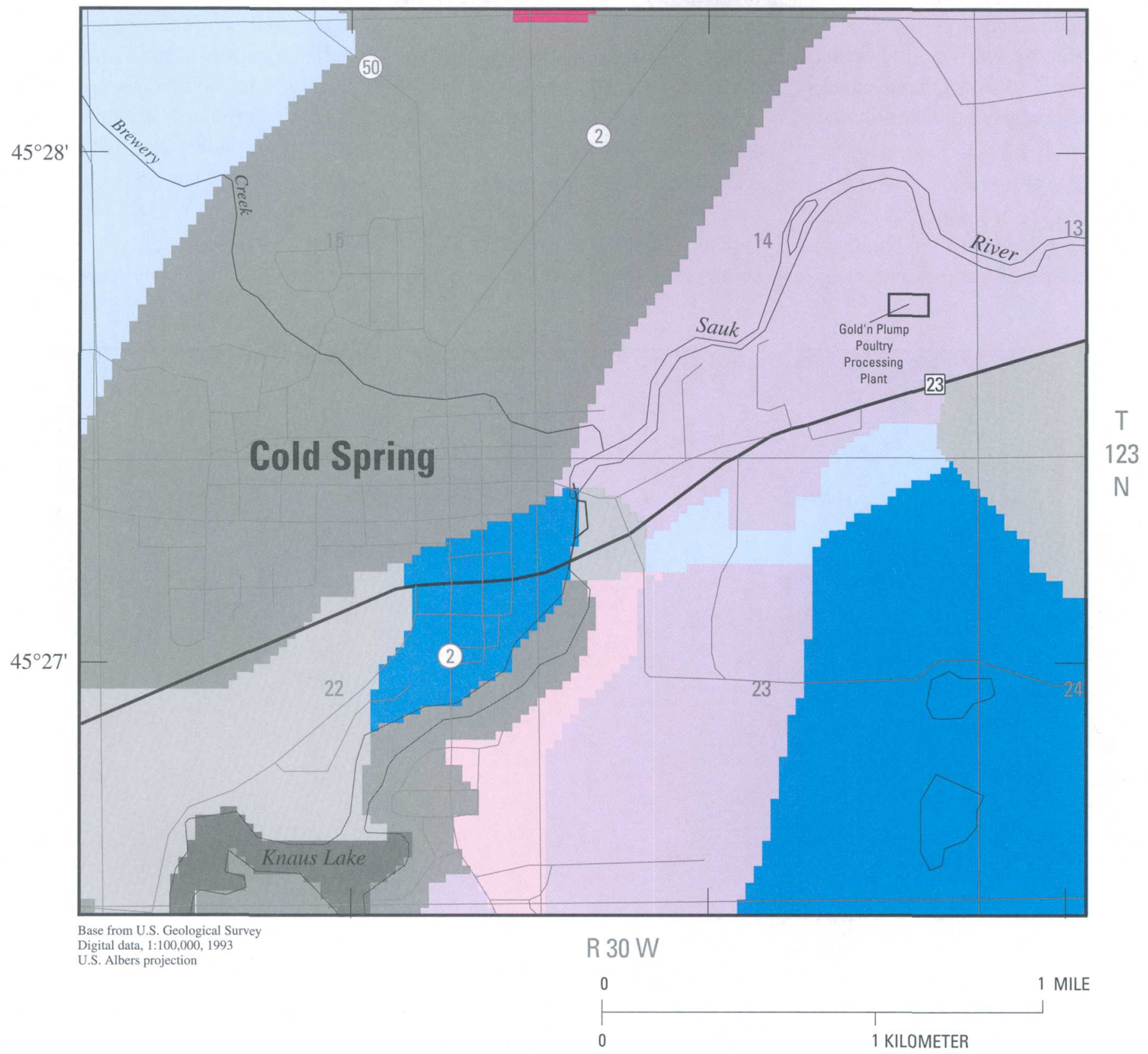

\section{EXPLANATION}

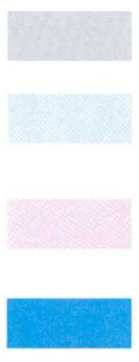

Inactive cells

Active cells assigned a horizontal hydraulic conductivity of 1 foot per day

Active cells assigned a horizontal hydraulic conductivity of 10 feet per day

Active cells assigned a horizontal hydraulic conductivity of 25 feet per day

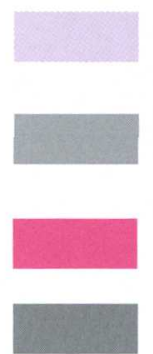

Active cells assigned a horizontal hydraulic conductivity of 200 feet per day

Active cells assigned a horizontal hydraulic conductivity of 300 feet per day

Active cells assigned a horizontal hydraulic conductivity of 350 feet per day

Constant head boundary

Figure 9a. Boundary conditions and calibrated horizontal hydraulic conductivity zones for ground-water-flow model layer 3 near Cold Spring and Gold'n Plump Poultry Processing Plant, Cold Spring area, Minnesota. 
and the northwestern and western boundaries for layer 4 are no-flow boundaries. The hydrogeologic units in these areas consist of clay and till, with predominantly vertical groundwater flow.

Constant-head cells were used for portions of the northern boundaries for layers 1 (upland surficial aquifer) and 3 (Sauk River Valley aquifer) and for the southwestern and a portion of the southeastern boundary for layer 3 (figs. 7 and 9). Constant heads were used for the southwestern boundary of layer 3 because it coincides with the chain of lakes. The stage altitudes for the lakes are relatively constant in time, with minimal seasonal and annual changes. The northern and southeastern constant-head bound- aries are downgradient from broad, poorly-defined highs in the potentiometric surfaces of the aquifers. These constant-head boundaries simulate inflow of ground water to the study area from sources of water beyond the study-area boundaries.

A specified-flux boundary was used to represent areal recharge to the upland surficial aquifer (layer 1) and

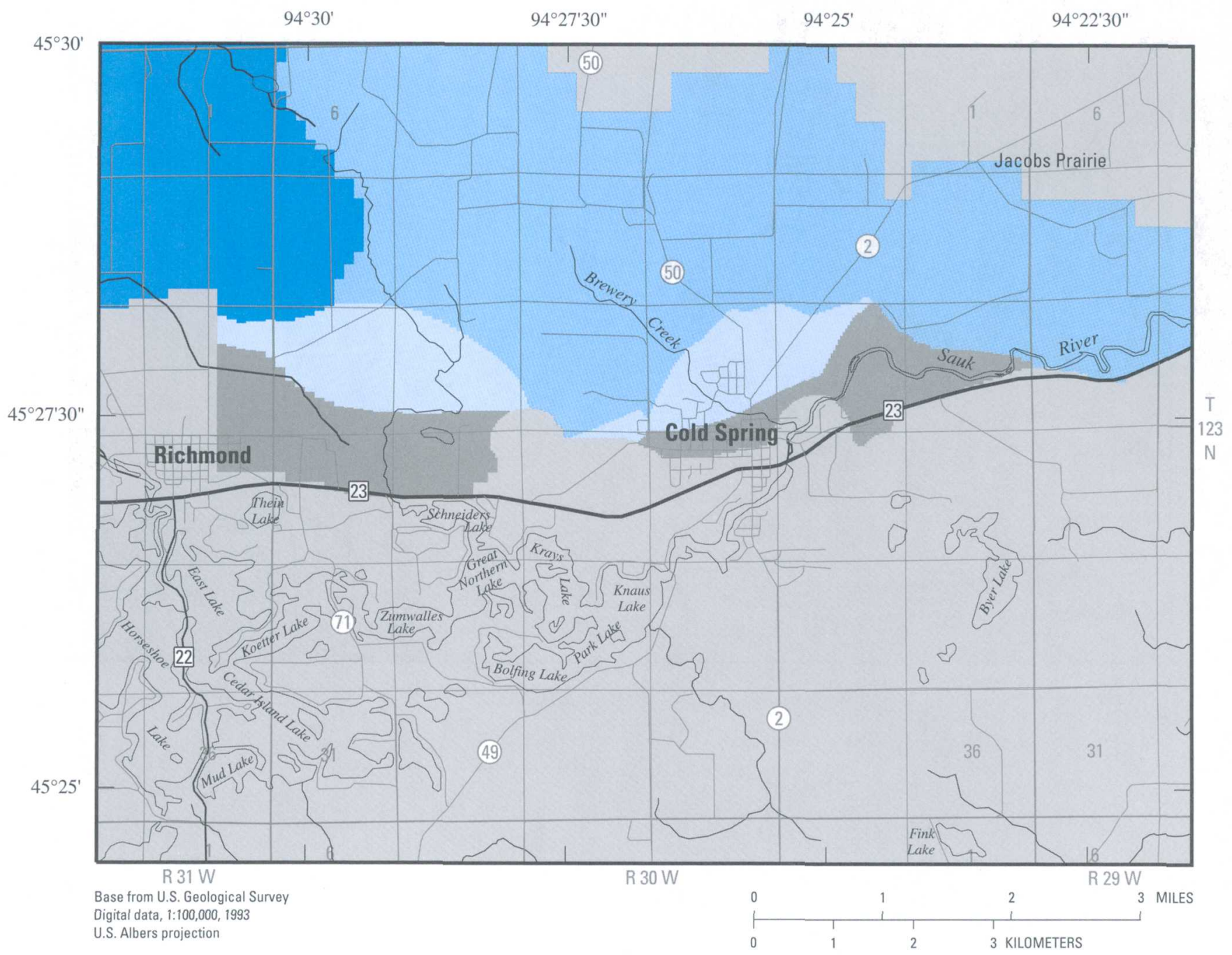

EXPLANATION

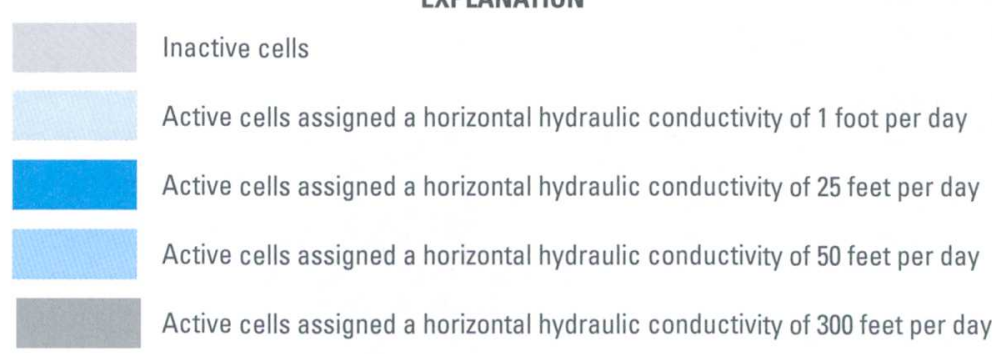

Figure 10. Extent, boundary conditions, and calibrated horizontal hydraulic conductivity zones for ground-water-flow model layer 4 , Cold Spring area, Minnesota. 
to the valley unit of the Sauk River Valley aquifer (layer 3) where it is the uppermost active model layer. Areal recharge to the aquifer represents the net difference between precipitation and evapotranspiration losses occurring above the water table. Areal recharge was applied to the highest active layer in each model cell.

Stream-aquifer leakage between the Sauk River and Brewery Creek and the valley unit of the Sauk River Valley aquifer (model layer 3) was simulated with head-dependent flux nodes (McDonald and Harbaugh, 1988 , chapter 6 ). The streams were divided into reaches, each of which is completely contained in a single cell. Stream-aquifer leakage through reach of streambed is approximated by Darcy's Law as

$$
\mathrm{QRIV}=(\mathrm{KLW} / \mathrm{M})(\mathrm{HRIV}-\mathrm{HAQ})
$$

where

$$
\text { QRIV = stream-aquifer leakage }
$$

through the reach of the streambed $\left(\mathrm{L}^{3} / \mathrm{T}\right)$,

$\mathrm{K}=$ vertical hydraulic conductivity of the streambed $(\mathrm{L} / \mathrm{T})$,

$\mathrm{L}=$ length of the reach $(\mathrm{L})$,

$\mathrm{W}=$ width of the stream $(\mathrm{L})$,

$\mathrm{M}=$ thickness of the streambed (L),

HRIV = head in the stream $(L)$, and

$\mathrm{HAQ}=$ head in the aquifer $(\mathrm{L})$.

The length of the streambed in each river cell was measured from USGS 7.5-minute-quadrangle topographic maps. The average width of the Sauk River streambed, estimated at stream stage and discharge measurement sites within the model area, is about $100 \mathrm{ft}$. Average streambed width for Brewery Creek is about $10 \mathrm{ft}$. The average streambed widths were used for every reach of the Sauk River and Brewery Creek. The thick- ness of the Sauk River and Brewery

Creek streambeds was assumed to be

$1 \mathrm{ft}$ for the model, as for other studies with numerical ground-water-flow models that simulated stream-aquifer leakage (Yager, 1993; Lindgren, 1990). The lower limit of the streambeds is poorly defined and not easily measurable. The initial value for vertical hydraulic conductivity of the streambed for the Sauk River and Brewey Creek was $1.0 \mathrm{ft} / \mathrm{d}$. Published values for vertical hydraulic conductivity of riverbed material for streams in glacial terrain commonly range from 0.1 to $10 \mathrm{ft} / \mathrm{d}$ (Norris and Fidler, 1969; Jorgensen and Ackroyd, 1973, Prince and others, 1987; Delin, 1990; Lindgren and Landon, 2000). Stream stage for each river cell was linearly interpolated between measured stream stage sites.

Discharge by ground-water evapotranspiration may occur from the shallow, unconfined portions of the aquifers (layers 1 and 3). The model simulates evapotranspiration from the saturated zone only. The initial maximum ground-water evapotranspiration rate specified in the model was 29 in./yr, which corresponds to the estimated average annual lake-evaporation rate in the model area (Baker and others, 1979). The ground-water evapotranspiration rate in the model decreases linearly with depth below land surface and becomes zero at the extinction depth. The extinction depth corresponds to a depth below land surface minimally greater than the rooting depth of the plants present. The plausible range for evapotranspiration extinction depth was assumed to be from 5 to $10 \mathrm{ft}$, with an initial uniform average value of $7 \mathrm{ft}$ specified in the model. The altitude of the land surface for each cell was determined from USGS 7.5minute-quadrangle topographic maps.

Ground water is withdrawn by high-capacity water-supply wells from the upland surficial aquifer (layer 1) and valley unit of the Sauk River Valley aquifer (layer 3). Ground-water withdrawal rates for 1998 were obtained from the records of the Minnesota Department of Health and local water suppliers. Total annual ground-water withdrawal rates from the upland surficial aquifer were $0.23 \mathrm{ft}^{3} / \mathrm{s}$ and from the valley unit of the Sauk River Valley aquifer were $2.83 \mathrm{ft}^{3} / \mathrm{s}$.

The initial and final calibrated values of hydraulic properties represented in the model are listed in table 2. Initial values for hydraulic conductivity for each hydrogeologic unit were based on the results of aquifer tests conducted in the study area and published values for similar hydrogeologic materials in the literature. Porosity values were derived from published values for similar hydrogeologic materials in the literature. The initial value for areal recharge was $7.0 \mathrm{in./yr}$, the average rate for 1999 estimated from hydrograph analysis. The ground-water evapotranspiration rate and extinction depth were assigned as explained above.

Different hydraulic conductivity values were assigned to each model layer within zones of differing geologic materials. Initially, layer 1, representing the upland surficial aquifer, included two hydraulic conductivity zones (table 2), based predominantly on the surficial geology shown in figure 3. Layer 2, representing the confining unit, was assigned uniform horizontal and vertical hydraulic conductivity values. The hydraulic conductivity zones for layers 3 and 4, representing the Sauk River Valley aquifer and its deeply buried unit, 


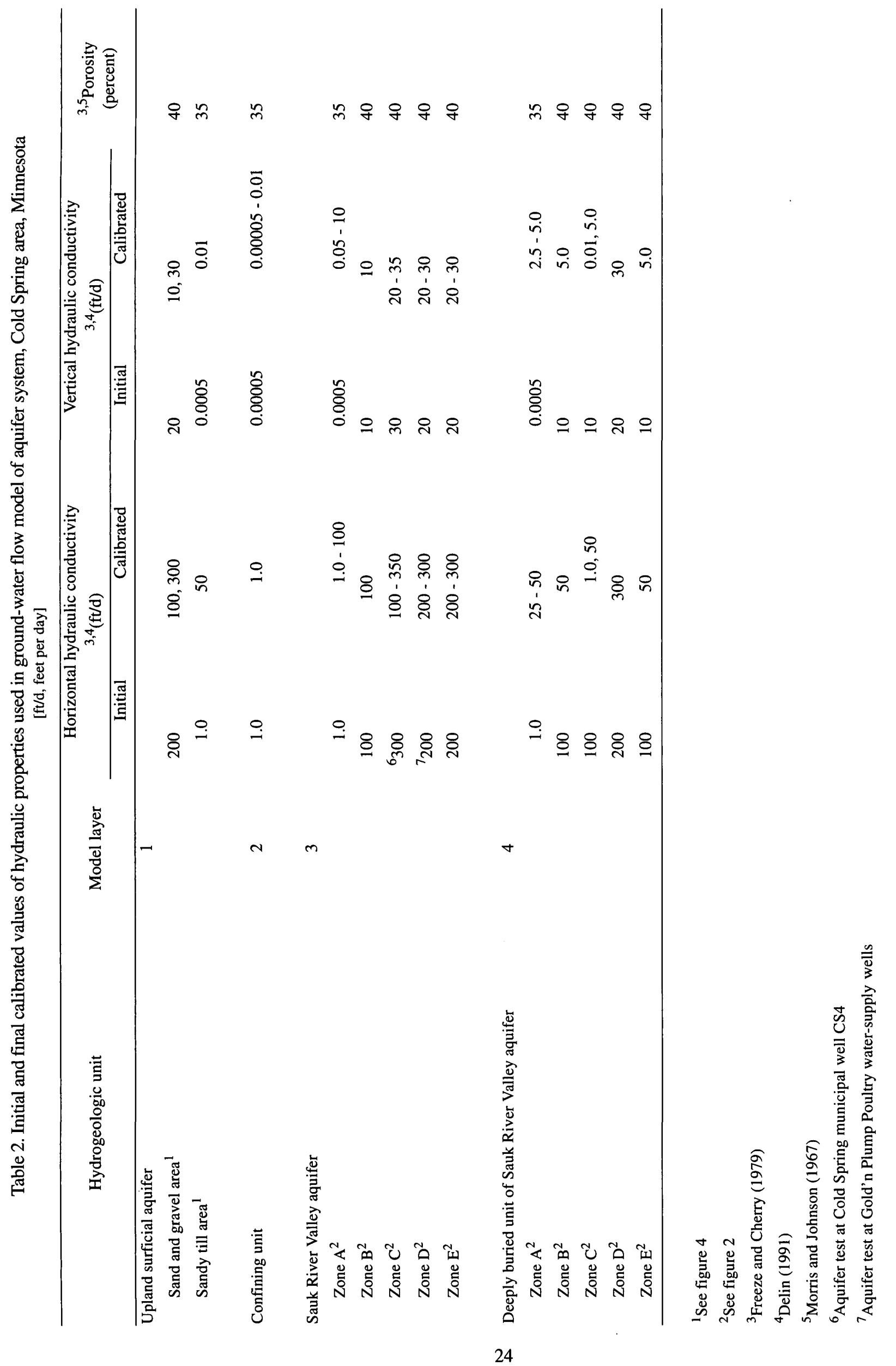


respectively, were based predominantly on the five zones of geologic deposits shown in figure 3 . In addition to the five zones shown in figure 3 , a zone was delineated for layer 3 and assigned the hydraulic conductivity values of zone $A$ in the area west and northwest of Cold Spring. The geologic materials in this area within the altitude interval of the Sauk River Valley aquifer (from land surface down to an altitude of $1,035 \mathrm{ft}$ ) are till and clay. This sixth zone includes the small area of mostly till (A) west of Cold Spring shown on figure 3, but was expanded based on an analysis of well logs in the area. An additional zone was also delineated for layer 3 in the vicinity of Cold Spring municipal well CS4. Well logs in this area indicated that the valley unit of the Sauk River Valley aquifer is composed of very coarse sand and gravel in this area. Therefore, a comparatively high horizontal hydraulic conductivity of $350 \mathrm{ft} / \mathrm{d}$ was assigned. The initial hydraulic conductivity zones for layer 4 are based on the composition of the geologic materials present below an altitude of $1,035 \mathrm{ft}$, and are derived from the zones shown in figure 3 and available well logs. In the zone of highest assigned horizontal hydraulic conductivity for layer $4(300 \mathrm{ft} / \mathrm{d})$, sand and gravel are present from land surface down to bedrock and the Sauk River Valley aquifer and its deeply buried unitareessentially one aquifer.

\section{Numerical Model Calibration and Results}

Model calibration is the process in which initial estimates of hydraulic properties and boundary conditions are adjusted until simulated hydraulic heads and flows acceptably match measured water levels and flows. For this study, hydraulic properties and areal recharge were adjusted within reasonable limits to produce an acceptable match between: (1) simulated hydraulic heads and measured water levels in wells during December 1998 and (2) simulated stream-aquifer leakage between the Sauk River and Brewery Creek and the valley unit of the Sauk River Valley aquifer and that estimated from measured streamflow during October 1998 and August 1999. Calibration and evaluation of the ground-water-flow model were conducted for steady-state (equilibrium) conditions. Long-term waterlevel data in many parts of Minnesota indicate that winter water levels approach and probably attain steadystate (equilibrium) in the groundwater system (Delin, 1990; Lindgren, 1990; Lindgren and Landon, 2000).

Therefore, changes in recharge to and discharge from the aquifer during winter are close to zero, and recharge and discharge can be considered to be in equilibrium.

The match between measured and simulated hydraulic heads and streamaquifer leakage was improved by: (1) subdividing the sand and gravel area of the upland surficial aquifer (layer 1) into two horizontal hydraulic conductivity zones (100 and $300 \mathrm{ft} / \mathrm{d}$ ), (2) increasing the horizontal and vertical hydraulic conductivities for the sandy till area of the upland surficial aquifer (layer 1), (3) increasing the vertical hydraulic conductivities of the confining unit (layer 2) near the eastern and southeastern margins of the confining unit and in the area of the valley of an unnamed stream that approximately bisects the upland surficial aquifer in the study area, (4) increasing the horizontal and vertical hydraulic conductivities for parts of geologic deposit zones A, C, D, and E for the Sauk River Valley aquifer (layer 3), (5) increasing the horizontal and vertical hydraulic conductivities for parts of geologic deposit zones A and D for the deeply buried unit of the Sauk
River Valley aquifer (layer 4), and (6) decreasing the horizontal and vertical hydraulic conductivities for parts of geologic deposit zones $\mathrm{B}, \mathrm{C}$, and $\mathrm{E}$ for the deeply buried unit of the Sauk River Valley aquifer (layer 4). The final calibrated values of hydraulic properties are given in table 2 and figures 7-10. The effect of increasing the vertical hydraulic conductivities of the confining unit was to increase leakage through the confining unit, thereby lowering hydraulic heads in the upland surficial aquifer and raising hydraulic heads in the Sauk River Valley aquifer. Changing the hydraulic conductivities of the hydrogeologic units in the model reflects the complexity of the glacial drift deposits, particularly in the upland areas. The changes are all within ranges of values reported by previous studies and aquifer test results in the Cold Spring area.

In addition to the changes in hydraulic conductivity values, additional zones of low hydraulic conductivity were necessary to improve the match between measured and simulated hydraulic heads. Low-conductivity zones of comparatively small areal extent, with horizontal hydraulic conductivities of 1.0 and $10 \mathrm{ft} / \mathrm{d}$, were simulated for the Sauk River Valley aquifer (layer 3) east of the Sauk River southeast of Cold Spring to maintain higher hydraulic heads for higher terrace-level saturated sand and gravel deposits in this area (figs. 9 and $9 \mathrm{a}$ ). The degree of hydraulic connection between these terrace deposits and the sand and gravel deposits at a lower altitude in the river valley is uncertain due to a lack of geologic logs. Low-conductivity zones of comparatively small areal extent were also simulated in the southeastern part of Cold Spring near the Sauk River ( $25 \mathrm{ft} / \mathrm{d}$, figs. 9 and 9a) and north of the Sauk River in T123N, R29W, sec- 
tion 18, and T123N, R30W, section 13 (10 ft/d, fig. 9). Geologic descriptions of these deposits in well logs supported these changes.

The match between measured and simulated hydraulic heads and stream-aquifer leakage was improved by increasing areal recharge to $8.0 \mathrm{in} . / \mathrm{yr}$ (initial value was $7.0 \mathrm{in} . / \mathrm{yr}$ ). The final rate $(8.0 \mathrm{in} . / \mathrm{yr})$ is within the range of reported areal recharge rates of 6.5 to $9.0 \mathrm{in}$./yr to surficial unconfined aquifers in Minnesota (Delin, 1988; Lindgren, 2000). The maximum ground-water evapotranspiration rate was not changed as a result of model calibration, but the extinction depth was reduced from $7 \mathrm{ft}$ to $5 \mathrm{ft}$.

\section{Hydraulic Heads}

The potentiometric surfaces computed by the model for the upland surficial and Sauk River Valley aquifers are similar to the contoured surfaces based on measured water levels and are considered to acceptably simulate directions of ground-water flow in the aquifers (figs. 4 and 5, respectively). The final simulated hydraulic heads were within $5 \mathrm{ft}$ of measured water levels in all but 5 of the 45 wells used to calibrate the model. The largest difference between measured and simulated hydraulic heads was $7.9 \mathrm{ft}$. The difference was $2.0 \mathrm{ft}$ or less at 24 of the wells. The mean absolute difference between measured and simulated hydraulic heads, computed as the sum of the absolute values of the differences divided by the number of wells (45) was $2.4 \mathrm{ft}$. The mean algebraic difference between measured and simulated hydraulic heads, computed as the algebraic sum of the differences divided by the number of wells, was $-0.9 \mathrm{ft}$, indicating a possible negative bias in the simulation of the hydraulic heads. However, the negative mean algebraic difference is caused by comparatively high negative differences for a few wells, and with the exclusion of these few wells the negative differences between measured and simulated hydraulic heads were approximately balanced by the positive differences.

\section{Stream-Aquifer Leakage}

Comparison of measured and simulated stream-aquifer leakage was also used to evaluate how well the model simulates the stream-aquifer system. Accuracy of the stream-discharge measurements conducted for this study was generally plus or minus 5-8 percent. Estimates of streamaquifer leakage are likely less than the measurement error for many of the Sauk River reaches. The August 1999 measurements downstream from SW4 were most representative of low-flow conditions and were used to evaluate the model calibration. The model generally duplicated the correct magnitude and direction of stream-aquifer leakage for the Sauk River and Brewery Creek, but the simulated streamaquifer leakage for the Sauk River was consistently less than the measured stream-aquifer leakage (table 1). The simulated gains in streamflow for the Sauk River reaches were within $8 \mathrm{ft}^{3} / \mathrm{s}$ of the measured gains, except for the reach between SW6 and SW7. The comparatively poor agreement between the measured and simulated loss in streamflow for the reach between SW6 and SW7 is probably due to measurement error, as indicated by the comparison between the measured streamflow losses and the volume of water pumped by nearby wells, discussed previously. The simulated gains in streamflow for the Brewery Creek reaches (SW10SW11 and SW11-SW12) were within $0.30 \mathrm{ft}^{3} / \mathrm{s}$ of the measured gains (table 1).

\section{Ground-Water Budget}

A water budget is an accounting of inflow to, outflow from, and stor- age change in the aquifers. For steady-state conditions, inflow (sources) to the aquifers equals outflow (discharges) from the aquifers (table 3), so that storage changes are zero. Areal recharge accounts for 51.5 percent of the sources of water to the aquifers in the Cold Spring area and inflow through constant-head boundaries contributes 45.8 percent (table 3). The remaining 2.7 percent comes from leakage from the streams to the valley unit of the Sauk River Valley aquifer. Most of the areal recharge occurs to the valley unit of the Sauk River Valley aquifer ( 74 percent) because this aquifer underlies most of the Cold Spring area. Eighty-six percent of the inflow through constanthead boundaries occurs to the Sauk River Valley aquifer. Ninety-three percent of the inflow through constant-head boundaries to the Sauk River Valley aquifer occurs through the northern model boundary, with 88 percent of the inflow through the northern model boundary occurring through the north-central part of the boundary. Only 6 percent of the inflow through constant-head boundaries to the Sauk River Valley aquifer occurs through the southeastern model boundary.

The largest discharges from the aquifers in the Cold Spring area are leakage from the valley unit of the Sauk River Valley aquifer to the Sauk River and Brewery Creek (53.7 percent) and outflow through constanthead boundaries (33.1 percent) (table 3). All but a minor amount of the outflow through constant-head boundaries occurs from the Sauk River Valley aquifer (94 percent). Most of the outflow through constant-head boundaries from the Sauk River Valley aquifer occurs in the southwestern part of the model area where the direction of ground-water flow is predominantly from east to west toward 
Table 3. Simulated water budgets from ground-water-flow model of aquifer system with 1998 and projected pumpage conditions, Cold Spring area, Minnesota

[Percent is percentage of total sources or of total discharges; $\mathrm{ft}^{3} / \mathrm{s}$, cubic feet per second]

\begin{tabular}{|c|c|c|c|c|}
\hline \multirow[b]{3}{*}{ Budget component and model layer } & \multicolumn{4}{|c|}{ Source } \\
\hline & \multicolumn{2}{|c|}{1998 pumpage conditions } & \multicolumn{2}{|c|}{ Projected pumpage conditions } \\
\hline & Rate $\left(\mathrm{ft}^{3} / \mathrm{s}\right)$ & Percent & Rate $\left(\mathrm{ft}^{3} / \mathrm{s}\right)$ & Percent \\
\hline \multicolumn{5}{|l|}{ Areal recharge } \\
\hline Layer 1 (Upland surficial aquifer) & 5.57 & 13.3 & 5.57 & 13.2 \\
\hline Layer 3 (Valley unit of Sauk River Valley aquifer) & 16.04 & 38.2 & 16.04 & 38.1 \\
\hline Subtotal & 21.61 & 51.5 & 21.61 & 51.3 \\
\hline \multicolumn{5}{|l|}{ Stream-aquifer leakage } \\
\hline Layer 3 (Valley unit of Sauk River Valley aquifer) & 1.13 & 2.7 & 1.09 & 2.6 \\
\hline Subtotal & 1.13 & 2.7 & 1.09 & 2.6 \\
\hline \multicolumn{5}{|l|}{ Inflow through constant-head boundary } \\
\hline Layer 1 (Upland surficial aquifer) & 2.59 & 6.2 & 2.60 & 6.2 \\
\hline Layer 3 (Sauk River Valley aquifer) & 16.63 & 39.6 & 16.65 & 39.9 \\
\hline Subtotal & 19.22 & 45.8 & 19.25 & 46.1 \\
\hline \multirow[t]{3}{*}{ Total } & 41.96 & 100.0 & 41.95 & 100.0 \\
\hline & \multicolumn{4}{|c|}{ Discharge } \\
\hline & \multicolumn{2}{|c|}{1998 pumpage conditions } & \multicolumn{2}{|c|}{ Projected pumpage conditions } \\
\hline Budget component and model layer & Rate $\left(\mathrm{ft}^{3} / \mathrm{s}\right)$ & Percent & Rate $\left(\mathrm{ft}^{3} / \mathrm{s}\right)$ & Percent \\
\hline \multicolumn{5}{|l|}{ Pumpage } \\
\hline Layer 1 (Upland surficial aquifer) & 0.23 & 0.6 & 0.23 & 0.5 \\
\hline Layer 3 (Sauk River Valley aquifer) & 2.83 & 6.7 & 3.06 & 7.3 \\
\hline Subtotal & 3.06 & 7.3 & 3.29 & 7.8 \\
\hline \multicolumn{5}{|l|}{ Stream-aquifer leakage } \\
\hline Layer 3 (Valley unit of Sauk River Valley aquifer) & 22.55 & 53.7 & 22.42 & 53.3 \\
\hline Subtotal & 22.55 & 53.7 & 22.42 & 53.3 \\
\hline \multicolumn{5}{|l|}{ Outflow through constant-head boundary } \\
\hline Layer 1 (Upland surficial aquifer) & 0.80 & 1.9 & 0.81 & 1.9 \\
\hline Layer 3 (Sauk River Valley aquifer) & 13.08 & 31.2 & 12.96 & 30.8 \\
\hline Subtotal & 13.88 & 33.1 & 13.77 & 32.7 \\
\hline \multicolumn{5}{|l|}{ Ground-water evapotranspiration } \\
\hline Layer 1 (Upland surficial aquifer) & 2.47 & 5.9 & 2.47 & 6.2 \\
\hline Subtotal & 2.47 & 5.9 & 2.47 & 6.2 \\
\hline Total & 41.96 & 100.0 & 41.95 & 100.0 \\
\hline
\end{tabular}

the Sauk River (72 percent). Twentyeight percent of the outflow is to the chain of lakes. The other discharges from the aquifers are withdrawals by wells ( 7.3 percent) and ground-water evapotranspiration (5.9 percent). Most of the withdrawals by wells are from the valley unit of the Sauk River Valley aquifer (92 percent). Ground- 
water evapotranspiration is a minor component of the water budget for the model area because ground-water levels are greater than $5 \mathrm{ft}$ below land surface, except for near the streams and some wetlands in the northwestern part of the study area.

The net stream-aquifer leakage is $21.42 \mathrm{ft}^{3} / \mathrm{s}$ from the valley unit of the Sauk River Valley aquifer to the Sauk River and Brewery Creek (table 3), indicating that the streams are gaining streams overall in the model area. This net discharge from the aquifer to the streams represents 52 percent of the sources of water to the aquifers other than the small amount of leakage from streams to the aquifers (areal recharge and inflow through constanthead boundaries). Ground-water withdrawals by supply wells represent only 7 percent of the sources of water to the aquifers.

Simulated leakage between model layers is in both downward and upward directions (table 4). However, other than for model layer 4, representing the deeply buried unit of the Sauk River Valley aquifer, upward movement of water is negligible. The large upward component of flow from model layer 4 to model layer 3, representing the Sauk River Valley aquifer, occurs predominantly near the Sauk River and chain of lakes, where ground water discharges to these surface-water bodies.

\section{Ground-Water Flow to Wells (1998 Conditions)}

The simulated steady-state contributing areas (time-of-travel zones for infinite travel time) for the WHP partnership water supply wells in the Cold Spring area, which are all screened the Sauk River Valley aquifer, may extend beyond the model boundaries to the north and to the southeast near the broad, poorly defined highs in the potentiometric surfaces of the aquifers (fig. 11). The contributing areas for the two Cold Spring Granite Company private water-supply wells and for Cold Spring municipal well CS3 extend into the area west and northwest of Cold Spring where the geologic materials within the altitude interval of the Sauk River Valley aquifer (from land surface down to an altitude of
$1,035 \mathrm{ft}$ ) are till and clay. The contributing areas for these wells generally are terminated at highs in the potentiometric surface of the Sauk River Valley aquifer in this area of low hydraulic conductivities. The contributing area for one of the Cold Spring Granite Company wells, however, extends to the north due to leakage downward from the upland surficial aquifer to the Sauk River Valley aquifer near the southern boundary of the upland surficial aquifer. The contributing areas for the Gold'n Plump Poultry Processing Plant supply wells extend: (1) to the Sauk River, (2) to the north to and possibly beyond the northern model boundary, and (3) to the southeast to and possibly beyond the southeastern model boundary. The contributing area extends to the north past the Sauk River where the pumped supply wells create a cone of depression that lowers ground-water levels at the river below the altitude of river stage (figs. 5a and 11a).

The simulated time required for water particles from the model boundaries to reach the WHP partnership water-supply wells varied. The simulated time-of-travel for water to reach

Table 4. Simulated leakage between model layers from ground-water-flow model of aquifer system with 1998 and projected pumpage conditions, Cold Spring area, Minnesota

[ $\mathrm{ft}^{3} / \mathrm{s}$; cubic feet per second]

\begin{tabular}{|c|c|c|c|c|}
\hline \multirow[b]{2}{*}{ Leakage between model layers } & \multicolumn{2}{|c|}{1998 pumpage conditions } & \multicolumn{2}{|c|}{ Projected pumpage conditions } \\
\hline & $\begin{array}{l}\text { Source } \\
\left(\mathrm{ft}^{3} / \mathrm{s}\right)\end{array}$ & $\begin{array}{c}\text { Discharge } \\
\left(\mathrm{ft}^{3} / \mathrm{s}\right)\end{array}$ & $\begin{array}{c}\text { Source } \\
\left(\mathrm{ft}^{3} / \mathrm{s}\right)\end{array}$ & $\begin{array}{c}\text { Discharge } \\
\left(\mathrm{ft}^{3} / \mathrm{s}\right)\end{array}$ \\
\hline \multicolumn{5}{|l|}{ Layer 1 (Upland surficial aquifer) } \\
\hline Through lower boundary & 0.0008 & 4.4312 & 0.0007 & 4.4625 \\
\hline \multicolumn{5}{|l|}{ Layer 2 (Confining unit) } \\
\hline Through upper boundary & 4.4312 & 0.0008 & 4.4625 & 0.0007 \\
\hline Through lower boundary & 0.0005 & 4.5501 & 0.0004 & 4.5848 \\
\hline \multicolumn{5}{|l|}{ Layer 3 (Sauk River Valley aquifer) } \\
\hline Through upper boundary & 4.5501 & 0.0005 & 4.5848 & 0.0004 \\
\hline Through lower boundary & 3.5067 & 3.5946 & 3.4864 & 3.5755 \\
\hline \multicolumn{5}{|c|}{ Layer 4 (Deeply buried unit of Sauk River Valley aquifer) } \\
\hline Through upper boundary & 3.5946 & 3.5067 & 3.5755 & 3.4864 \\
\hline Total & 16.0839 & 16.0839 & 16.1103 & 16.1103 \\
\hline
\end{tabular}


the Cold Spring Alano Society and Gluek Brewing Company supply wells and Cold Spring municipal wells CS1 and CS2 from the northern model boundary is about 15 years. The simulated time-of-travel for water to reach the Town's Edge Mobile Home Park and Gold'n Plump Poultry Processing Plant supply wells from the southeastern model boundary is about 75 years. The time-of-travel for water to reach the Town's Edge Mobile Home Park and Gold'n Plump Poultry Processing Plant supply wells is much greater over a shorter distance than for the Cold Spring Alano Society wells, Gluek Brewing Company wells, and Cold Spring municipal wells CS1 and CS2 because their time-of-travel zones include areas of low hydraulic conductivities ( 1 and $25 \mathrm{ft} / \mathrm{d}$ ) (figs. 8-9a). The simulated time-of-travel for water to reach the two Cold Spring Granite Company supply wells and Cold Spring municipal well CS3 from highs in the potentiometric surface of the Sauk River Valley aquifer (layer 3) in the area of low hydraulic conductivities to the north and northwest of the wells is also 50 to 75 years. Water from the northern model boundary reaches the Gold'n Plump Poultry Processing

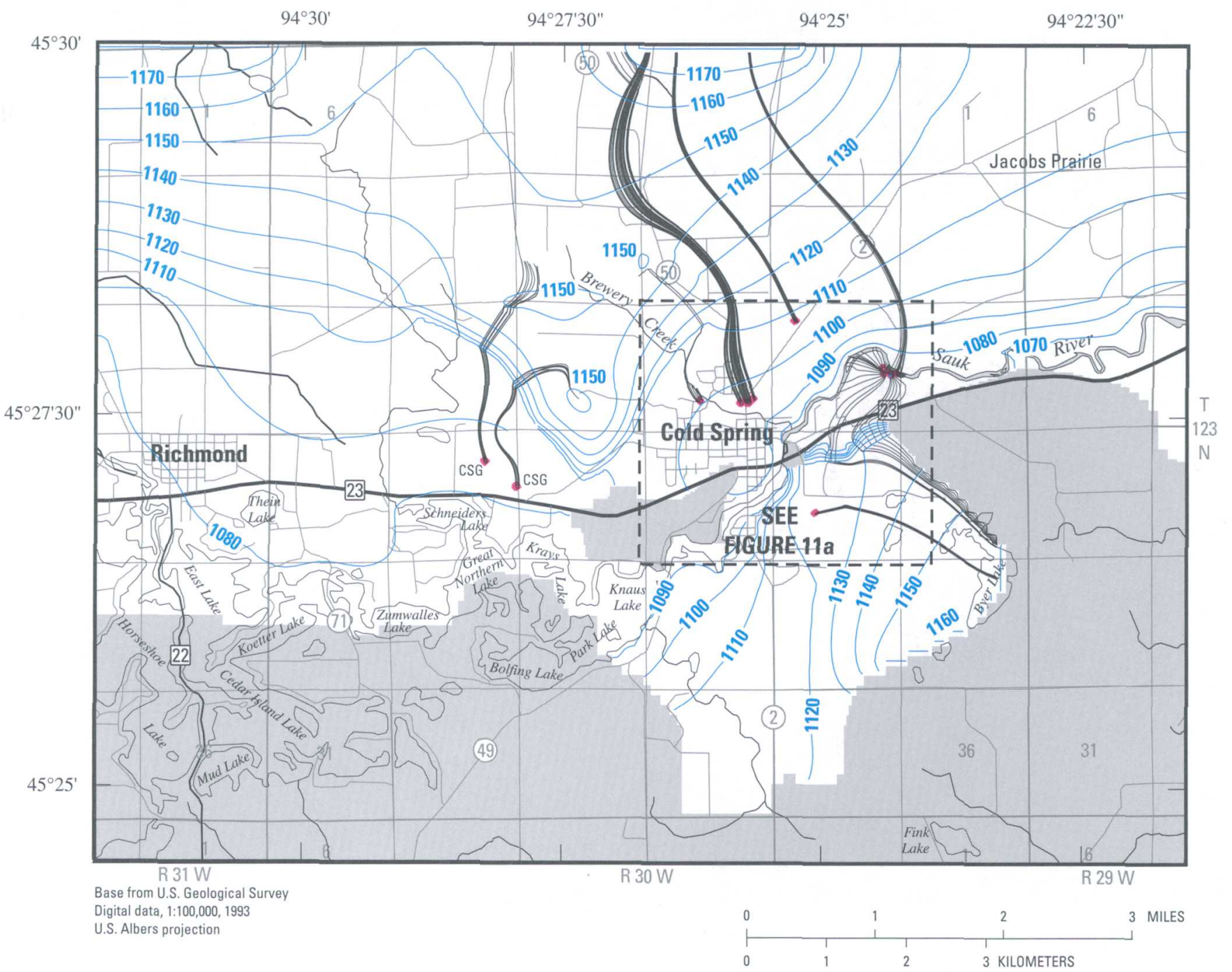

EXPLANATION
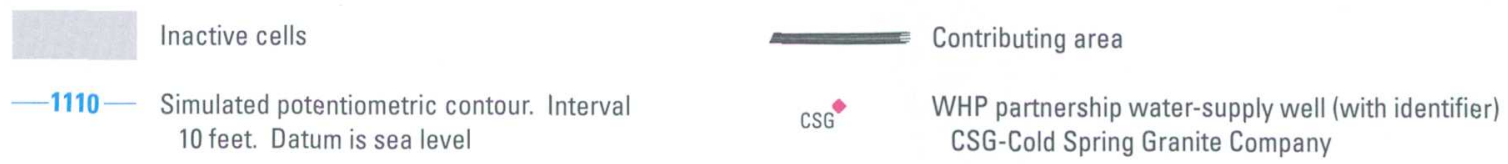

Figure 11. Simulated altitude of potentiometric surface of Sauk River Valley aquifer and contributing areas of ground-water flow to water-supply wells, 1998 pumpage, Cold Spring area, Minnesota. 


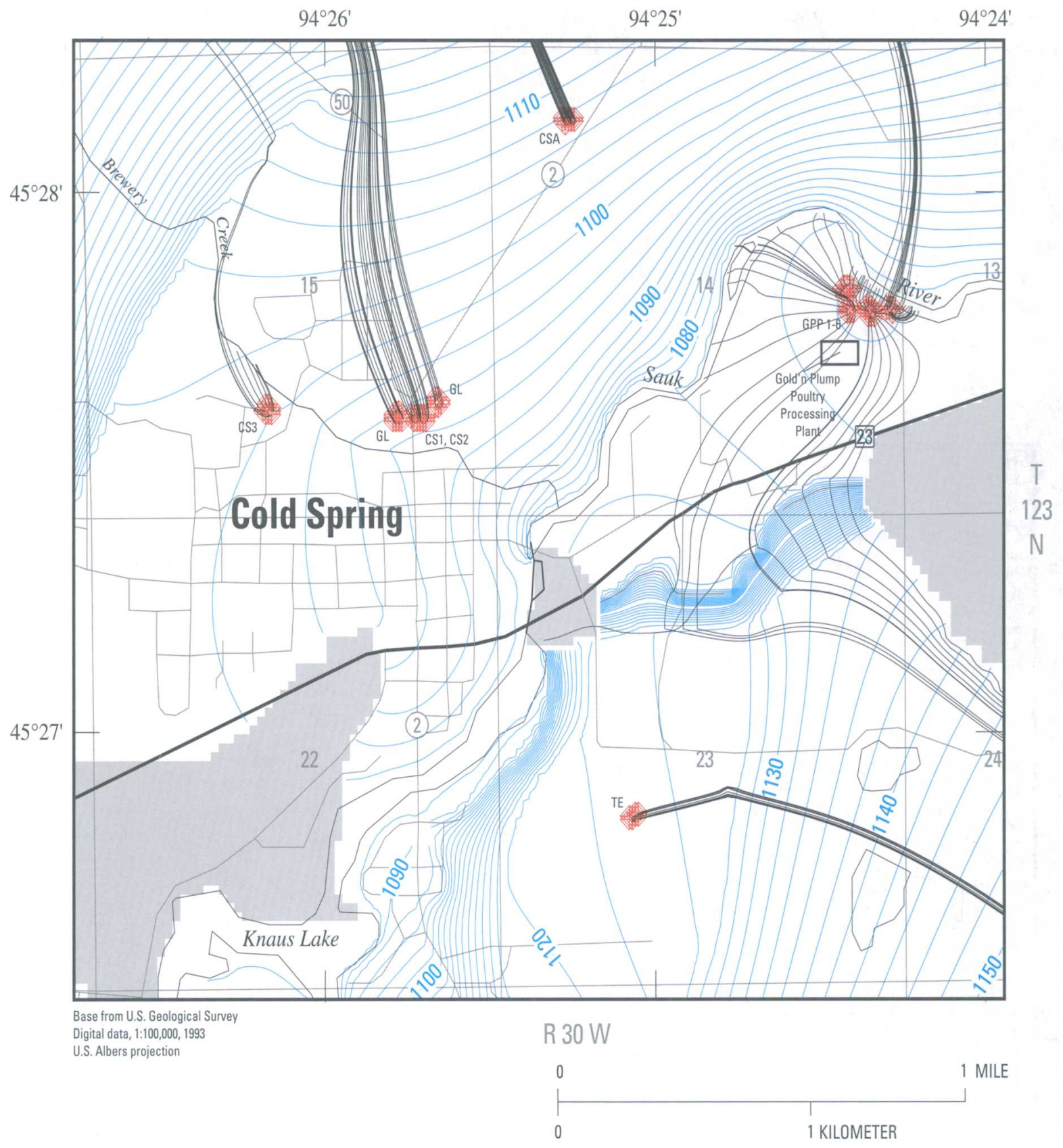

EXPLANATION
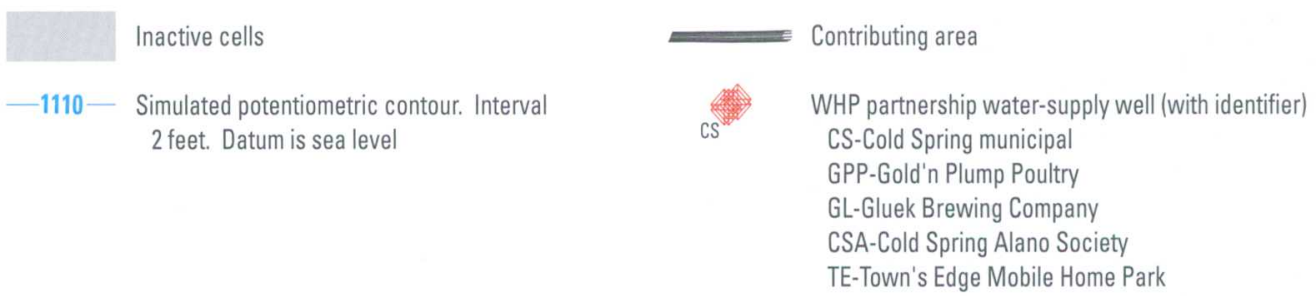

Figure 11a. Simulated altitude of potentiometric surface of Sauk River Valley aquifer and contributing areas of ground-water flow to water-supply wells near Cold Spring and Gold'n Plump Poultry Processing Plant, 1998 pumpage, Cold Spring area, Minnesota. 
Plant supply wells in about 10 years. The simulated travel time is much shorter than for water from the southeastern model boundary because the hydraulic conductivity of the geologic material in the contributing area extending to the north is greater than that in the contributing area extending to the southeast. The simulated timeof-travel for water to reach the Gold'n Plump Poultry Processing Plant supply wells from the Sauk River ranges from less than 1 year for the river reach near the supply wells where induced infiltration of river water occurs to about 5 years for the reaches to the northwest and west of the wells.

It is important in the analysis and application of the simulated contributing areas to recognize that the model results are for steady-state conditions. Therefore, all stresses on the aquifer system, including pumping rates, stream-aquifer leakage, and areal recharge, are simulated as constant in time. Real pumping rates and aquifer recharge and discharge vary seasonally, however, thus altering the timeof-travel zones for a well. Also the simulated time-of-travel zones may differ under steady-state conditions with different pumping rates and precipitation regimes.

\section{Effects of Increased Ground- Water Withdrawals}

A model simulation was done to evaluate the response of the streamaquifer system in the model area to projected increases in ground-water withdrawals and to delineate 10,20 , and 30-year time-of-travel zones for the WHP partnership water-supply wells under these conditions. At the cooperators request only the 20 year time-of-travel zone were included in this report. The 20 and 30 -year timeof-travel zones were similar. The total projected increase in ground-water withdrawals estimated by the WHP partnership well owners was $0.23 \mathrm{ft}^{3} / \mathrm{s}$, an increase of 7.5 percent. The projected increases were 10 percent for the Gluek Brewing Company and Town's Edge Mobile Home Park supply wells, 12 percent for the Gold'n Plump Poultry Processing Plant supply wells, and 28 percent for the Cold Spring municipal wells. For the Cold Spring municipal wells, the increased withdrawals would be from well CS4, which began pumping in November 1999, and well CS5, which has not yet been installed. The projected annual withdrawals from municipal wells CS2 and CS3 are 68.8 million gallons $\left(0.29 \mathrm{ft}^{3} / \mathrm{s}\right)$ less than during 1998 , a decrease in these two wells of 51 percent. No increase in ground-water withdrawals from the Cold Spring Granite Company and Cold Spring Alano Society supply wells was projected. The 1998 reported withdrawal rates for irrigation wells were used in the simulation with projected increased groundwater withdrawals from the WHP partnership water-supply wells. Withdrawal rates for irrigation have been relatively stable during recent years and no appreciable increase is foreseen, other than that due to lowerthan-normal precipitation. The final calibrated values for all model parameters, including an areal recharge rate of $8.0 \mathrm{in} . / \mathrm{yr}$, were used in the simulation with projected increased groundwater withdrawals.

The primary effects of the projected increased ground-water withdrawals were to: (1) decrease outflow from the Sauk River Valley aquifer through constant-head boundaries and (2) decrease leakage from the valley unit of the Sauk River Valley aquifer to the streams (table 3 ). The additional water pumped by wells $\left(0.23 \mathrm{ft}^{3} / \mathrm{s}\right)$ was derived from a net increase of $0.14 \mathrm{ft}^{3} / \mathrm{s}$ in the flow of water to the study area through con- stant-head boundaries and a net decrease of $0.09 \mathrm{ft}^{3} / \mathrm{s}$ in leakage of water from the aquifer to the streams. The net increase in the flow of water to the study area through constanthead boundaries was due primarily to a decrease of $0.12 \mathrm{ft}^{3} / \mathrm{s}$ in outflow from the Sauk River Valley aquifer (table 3). The projected increased ground-water withdrawals also resulted in: (1) increased leakage downward from the upland surficial aquifer (layer 1) through the confining unit (layer 2) to the Sauk River Valley aquifer (layer 3) and (2) decreased leakage downward from the Sauk River Valley aquifer to the deeply buried unit of the Sauk River Valley aquifer (layer 4) (table 4).

No appreciable differences are discernible between the simulated steady-state potentiometric surfaces and contributing areas to wells with 1998 pumpage and those with the projected pumpage (compare figs. 11$12 \mathrm{a})$, due to the relatively small projected increase in ground-water withdrawals $\left(0.23 \mathrm{ft}^{3} / \mathrm{s}\right)$. The 20 -year time-of-travel zones for the WHP partnership water-supply wells reach either the model-area boundaries or predominantly clay and till areas for the Sauk River Valley aquifer (fig. 12). Water from the northern boundary of the model area reaches the Cold Spring municipal wells CS4 and CS5 in about 7 years. For wells with 20 year time-of-travel zones limited to the unconfined, surficial sand and gravel areas of the Sauk River Valley aquifer, the 20-year time-of-travel zones and contributing areas coincide. For wells with contributing areas that include lower hydraulic conductivity ( $25 \mathrm{ft} / \mathrm{d}$ or less) geologic materials, the 20-year time-of-travel zones are smaller than the contributing areas due to the much slower travel times through the lower hydraulic conductivity materials. 


\section{Numerical Model Limitations and Accuracy of Results}

A numerical ground-water-flow model is a practical tool for simulating response of the stream-aquifer system to anticipated changes in areal recharge and ground-water withdrawals imposed on the system. A model is a simplification of a complex flow system. The accuracy of the simulations is limited by the accuracy of the data used to describe the properties of the aquifers and the confining units, areal recharge rates, ground-water withdrawal rates, streambed hydraulic conductivities, and boundary conditions. In addition, a combination of these inputs to the model different from that used in a simulation could produce the same result.

Use of the calibrated model as a predictive tool is based on the premise that if historical conditions in the aquifer can be simulated, then future similar hydrologic conditions can also be simulated. The variation in areal recharge and discharge occurring during the simulation of hypothetical conditions should be similar to that for the calibration simulation. The accuracy of simulation results for hypothetical conditions becomes more uncertain if the variation in areal

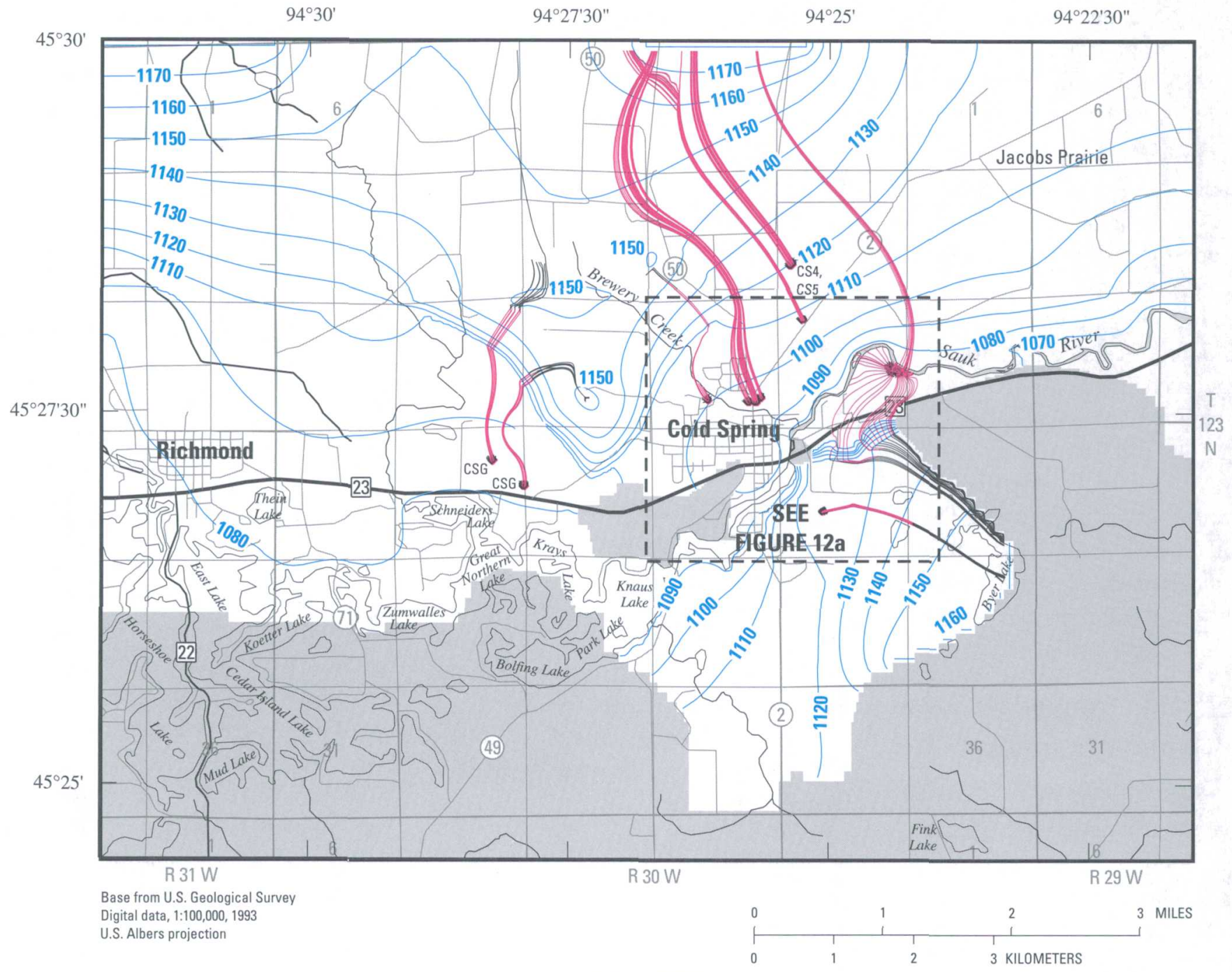

EXPLANATION
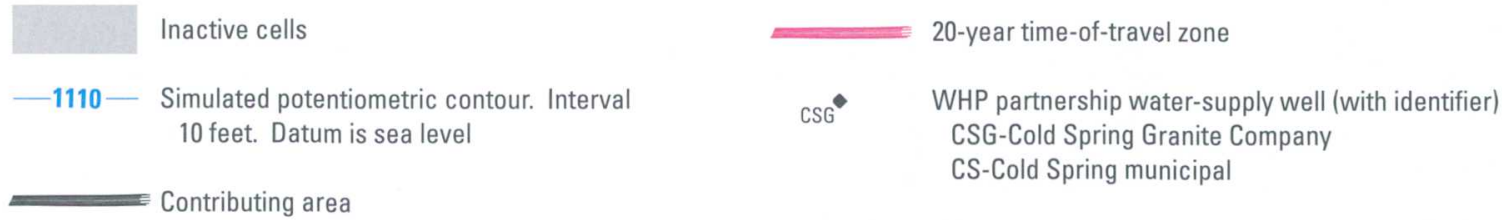

Figure 12. Simulated altitude of potentiometric surface of Sauk River Valley aquifer, contributing areas, and 20-year time-of-travel zones of ground-water flow to water-supply wells, projected pumpage, Cold Spring area, Minnesota. 


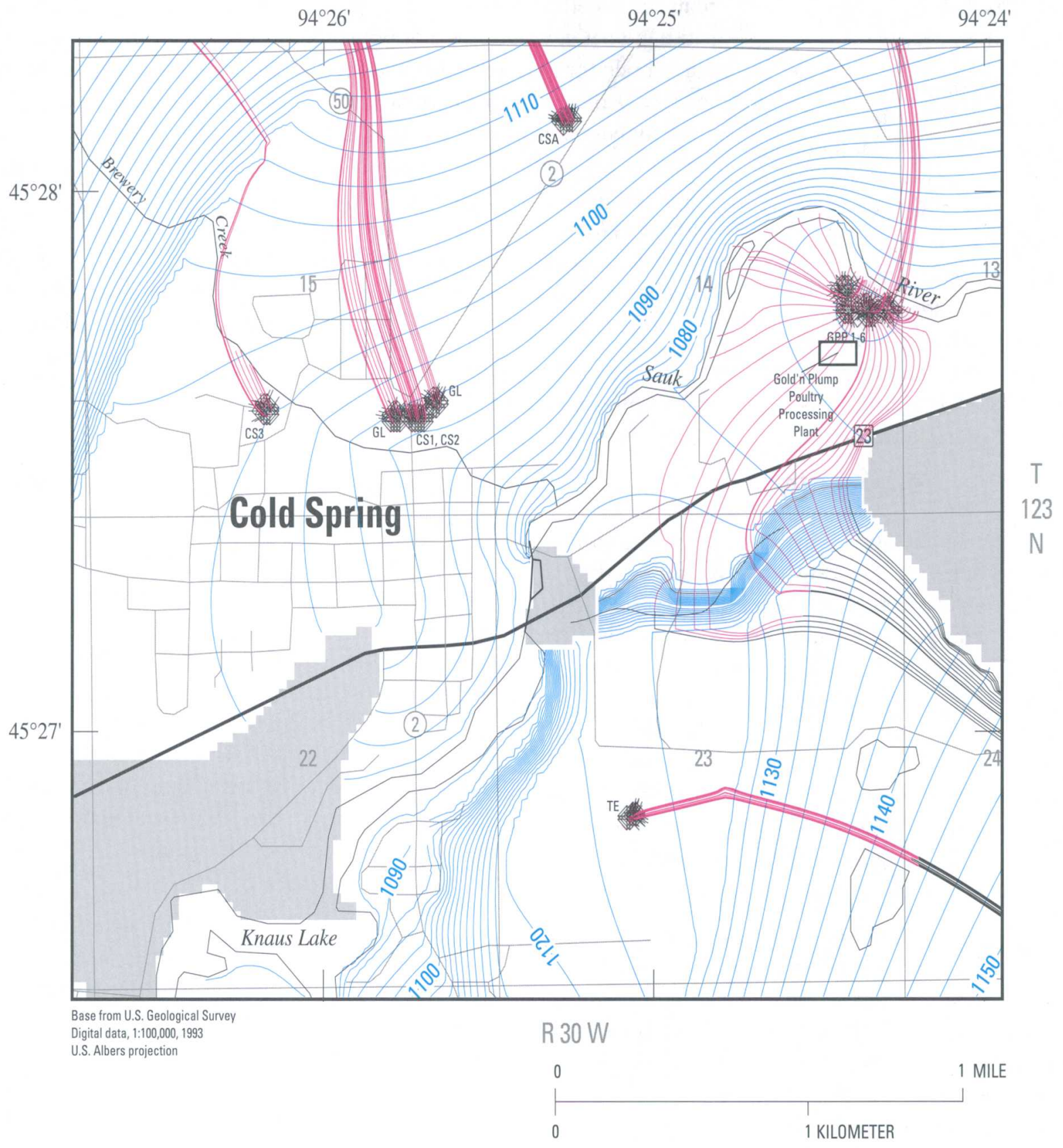

EXPLANATION
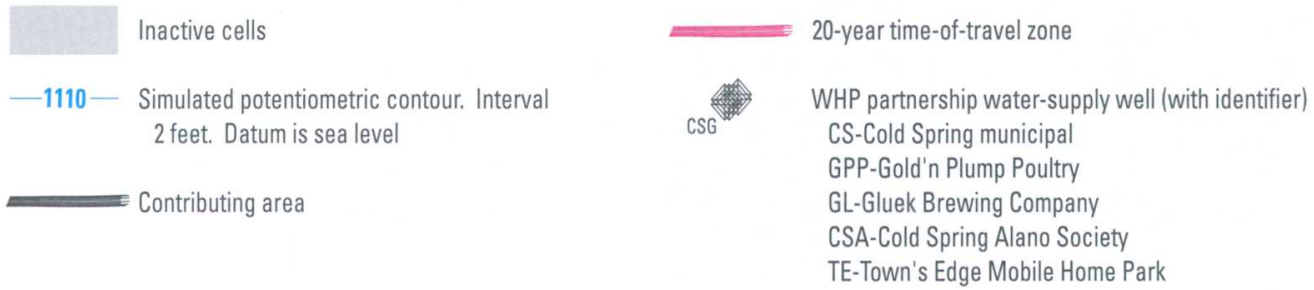

Figure 12a. Simulated altitude of potentiometric surface of Sauk River Valley aquifer, contributing areas, and 20-year time-of-travel zones of ground-water flow to water-supply wells near Cold Spring and Gold'n Plump Poultry Processing Plant, projected pumpage, Cold Spring area, Minnesota. 
recharge and discharge exceeds the range used in calibration.

The accuracy of simulations of hypothetical conditions varies depending on the particular conditions being simulated. Factors affecting the accuracy of the simulations include:

(1) the duration of the simulation period compared to the duration of the calibration period, and (2) the rate of simulated areal recharge or discharge compared to those used in calibration. Assuming the model calibration is accurate, the most accurate simula-

\section{SUMMARY}

Increased demand for ground water in the Cold Spring area in central Minnesota has resulted in the increased development of glacially-deposited aquifers. Surficial and buried sand and gravel aquifers underlie the Sauk River Valley in the Cold Spring area and are utilized as sources of water supply. Areas contributing ground-water to highcapacity wells need to be delineated so that land use within the contributing areas can be managed to reduce the risk of water-quality degradation. To address these needs and concerns, and to further the understanding of stream-aquifer systems, the U. S. Geological Survey, in cooperation with the city of Cold Spring, conducted a study during 1998-99.

Surficial deposits in the Cold Spring area consist mainly of late-Wisconsin glacial till and outwash sands and gravels associated with the Des Moines and Superior lobes. Outwash sands and gravels from the Des Moines lobe fill most of the Sauk River Valley. The Quaternary deposits in the study area include: (1) thick surficial sand and gravel outwash deposits, (2) complex till and ice-contact stratified deposits that may include surficial or buried sand, sand and gravel lenses, or both, and (3) till with few, if any, buried sand and gravel lenses. Glacial deposits with thicknesses of as much as $50 \mathrm{ft}$ are present along the river, whereas thicknesses of as much as $250 \mathrm{ft}$ are present in the uplands northwest and southwest of Cold Spring. Precambrian igneous and metamorphic rocks underlie the glacial deposits in the Cold Spring area.

Surficial aquifers underlie a portion of the uplands in the north-central part of the study area and the Sauk River Valley. The upland surficial aquifer, underlying the uplands in the north-central part of the study area, includes areas of: (1) Superior lobe ice-contact and outwash deposits and (2) predominantly sandy Superior lobe till, with isolated surfi- drawals done for this study is similar to the rate of ground-water withdrawals used in the calibration simulation. The total annual ground-water withdrawal rate used in the simulation with projected ground-water withdrawals is only 7.5 percent greater than the rate used in the calibration simulation. The simulated areal recharge rate is the same in the calibration and projected ground-water withdrawals simulations.

The Sauk River Valley aquifer consists of hydraulically connected sand and gravel units with two different hydrogeologic settings: (1) the generally continuous surficial unconfined unit underlying the Sauk River Valley (valley unit) and (2) buried confined units that are overlain by till or lake clays in the upland areas. Maximum saturated thickness of the valley unit of the aquifer is about $50 \mathrm{ft}$. Buried units of the aquifer that are in hydraulic connection with the valley unit of the aquifer are present in the north-central and northwestern parts of the study area. Thicknesses of the buried units are generally 10 to $20 \mathrm{ft}$.

Ground-water flow in the upland surficial aquifer is (1) to the south and southeast toward the margins of the aquifer and (2) from the uplands toward an unnamed creek valley in the central part of the aquifer. Ground-water flow in the Sauk River Valley aquifer is from upland areas toward the Sauk River and the connected chain of lakes. The aquifer is under unconfined conditions throughout most of its areal extent, but is under confined conditions where it is buried by till and clay in the northwestern part of the study area.

The primary sources of water to the aquifers are (1) areal recharge and (2) ground-water flow through the northern boundary. Based on hydrograph analysis, ground-water recharge rates to the aquifers during 1999 ranged from 5.3 to $8.6 \mathrm{in./yr}$, with an average value of $7.0 \mathrm{in} . / \mathrm{yr}$. Sources of water to the Sauk River Valley aquifer also include: (1) leakage of water through overlying till and clay for buried units of the aquifer and (2) probably ground-water flow from undifferentiated glacial deposits in the southeastern part of the study area.

Discharge from the aquifers is by (1) withdrawals from wells, (2) leakage to streams, and (3) ground-water evapo- 
transpiration in areas where the water table is within 5$10 \mathrm{ft}$ of land surface. Discharge from the upland surficial aquifer is also by leakage downward through a till and clay confining unit to the buried units of the Sauk River Valley aquifer. Discharge from the Sauk River Valley aquifer to surface water is to the Sauk River, chain of lakes, and Brewery Creek.

Streamflow measurements indicated net gains of 44.8 and $25.8 \mathrm{ft}^{3} / \mathrm{s}$ for the Sauk River from Cold Spring to Rockville, located about one mile east of the study area, during October 1998 and August 1999, respectively. In general, the Sauk River probably is a gaining stream in all reaches, except for the reach adjacent to the Gold'n Plump Poultry Processing Plant well field. Ground-water withdrawals from the well field result in declines in the potentiometric surface of the aquifer near the supply wells, thereby inducing infiltration of water from the Sauk River to the underlying aquifer. The streamflow gains in the river reaches downstream from Brewey Creek, other than the reach adjacent to the Gold'n Plump Poultry Processing Plant well field, during August 1999 ranged from 9.0 to $12 \mathrm{ft}^{3} / \mathrm{s}$. The measured gains in streamflow for Brewery Creek were 2.75 and $2.25 \mathrm{ft}^{3} / \mathrm{s}$ during October 1998 and August 1999 , respectively.

A numerical ground-water-flow model was constructed and calibrated for steady-state conditions. The match between measured and simulated hydraulic heads and stream-aquifer leakage was improved by increasing areal recharge from $7.0 \mathrm{in./yr}$, the initial value based on hydrograph analysis, to $8.0 \mathrm{in./yr}$. Areal recharge accounts for 51.5 percent of the sources of water to the aquifers in the Cold Spring area and inflow through constant-head boundaries contributes 45.8 percent. The remaining 2.7 percent comes from leakage from the streams to the valley unit of the Sauk River Valley aquifer. Most of the areal recharge occurs to the valley unit of the Sauk River Valley aquifer (74 percent). Eighty-six percent of the inflow through constant-head boundaries occurs to the Sauk River Valley aquifer. Ninety-three percent of the inflow through constant-head boundaries to the Sauk River Valley aquifer occurs through the northern model boundary.

The largest discharges from the aquifers in the Cold Spring area are leakage from the valley unit of the Sauk River Valley aquifer to the Sauk River and Brewery Creek (53.7 percent) and outflow through constant-head boundaries (33.1 percent). All but a minor amount of the outflow through constant-head boundaries occurs from the Sauk River Valley aquifer (94 percent). The other discharges from the aquifers are withdrawals by wells ( 7.3 percent) and ground-water evapotranspiration (5.9 percent). The net stream-aquifer leakage is $21.42 \mathrm{ft}^{3} / \mathrm{s}$ from the valley unit of the Sauk River Valley aquifer to the Sauk River and Brewery Creek. This net discharge from the aquifer to the streams represents 52 percent of the sources of water to the aquifers (areal recharge and inflow through constant-head boundaries).

The simulated steady-state contributing areas (time-oftravel zones for infinite travel time) for the WHP partnership water-supply wells in the Cold Spring area may extend beyond the model boundaries to the north and to the southeast near the broad, poorly defined highs in the potentiometric surfaces of the aquifers. The contributing areas for the Gold'n Plump Poultry Processing Plant supply wells extend: (1) to the Sauk River, (2) to the north to and possibly beyond the northern model boundary, and (3) to the southeast to and possibly beyond the southeastern model boundary. The contributing area extends to the north past the Sauk River where the pumped supply wells create a cone of depression that lowers ground-water levels at the river below the altitude of river stage. The simulated timeof-travel for water to reach the Cold Spring Alano Society, Gluek Brewing Company, and Gold'n Plump Poultry Processing Plant supply wells and Cold Spring municipal wells CS1 and CS2 from the northern model boundary is about 10 to 15 years. The simulated time-of-travel for water to reach the Town's Edge Mobile Home Park and Gold'n Plump Poultry Processing Plant supply wells from the southeastern model boundary is about 75 years. The simulated time-of-travel for water to reach the Gold'n Plump Poultry Processing Plant supply wells from the Sauk River ranges from less than 1 year for the river reach near the supply wells where induced infiltration of river water occurs to about 5 years for the reaches to the northwest and west of the wells.

The response of the stream-aquifer system in the model area to projected increases in ground-water withdrawals of $0.23 \mathrm{ft}^{3} / \mathrm{s}$, an increase of 7.5 percent, was evaluated. The primary effects of the projected increased ground-water withdrawals were to: (1) decrease outflow from the Sauk River Valley aquifer through constant-head boundaries and (2) decrease leakage from the valley unit of the Sauk River Valley aquifer to the streams. No appreciable differences are discernible between the simulated steady-state potentiometric surfaces and contributing areas to wells with 1998 pumpage and those with the projected pumpage. The 20year time-of-travel zones reach either the model-area boundaries or predominantly clay and till areas for the Sauk River Valley aquifer. 


\section{REFERENCES CITED}

Baker, D.G., and Kuehnast, E.A., 1978, Climate of Minnesota Part X, Precipitation normals for 1941-70: Minnesota Agricultural Experiment Station Technical Bulletin 314, 15 p.

Baker, D.G., Nelson, W.W., and Kuehnast, E.A., 1979, Climate of Minnesota, Part XII, The hydrologic cycle and soil and water: Minnesota Agricultural Experiment Station Technical Bulletin $322,23 \mathrm{p}$.

Delin, G.N., 1988, Geohydrology and water quality of confined-drift aquifers in the Brooten-Belgrade area, west-central Minnesota: U.S. Geological Survey Water-Resources Investigations Report 88-4124, 138 p. 1990, Hydrogeology and simulation of ground-water flow in the Rochester area, southeastern Minnesota, 1987-88: U.S. Geological Survey Water-

Resources Investigations Report 90-4081, 102 p. 1991, Simulation of effects of ground-water development on water levels in glacial-drift aquifers in the Brooten-Belgrade area, west-central Minnesota: U.S. Geological Survey Water-Resources Investigations Report 88-4193, 66 p.

Freeze, R.A., and Cherry, J.A., 1979, Groundwater: Englewood Cliffs, New Jersey, PrenticeHall, Inc., 604 p.

Guiguer, N., and Franz, T., 1999, Visual MODFLOW user's manual, ver. 2.8: Waterloo, Ontario, Canada, Waterloo Hydrogeologic Inc., 282 p.

Helgesen, J.O., Ericson, D.W., and Lindholm, G.F., 1975, Water resources of the Mississippi and Sauk Rivers watershed, central Minnesota: U.S. Geological Survey Hydrologic Investigations Atlas HA-534, 3 plates.
HDR Engineering, Inc., 1995, Ground-water resources evaluation-Well head protection area (WHPA) delineation: Report prepared for Gold'n Plump Poultry, $120 \mathrm{p}$.

Jorgensen, D.G., and Ackroyd, E.A., 1973, Water resources of the Big Sioux River valley near Sioux Falls, South Dakota: U.S. Geological Survey Water-Supply Paper 2024, 50 p.

Lindgren, R.J., 1990, Simulation of ground-water flow in the Prairie du Chien-Jordan and overlying aquifers near the Mississippi River, Fridley, Minnesota: U.S. Geological Survey WaterResources Investigations Report 90-4165, 152 p.

Lindgren, R.J., and Landon, M.K., 2000, Effects of ground-water withdrawals on the Rock River and associated valley aquifer, eastern Rock County, Minnesota: U.S. Geological Survey Water-Resources Investigations Report 98-4157, 103 p.

Lindholm, G.F., 1980, Ground-water appraisal of sand plains in Benton, Sherburne, Stearns, and Wright Counties, central Minnesota: U.S. Geological Survey Water-Resources Investigations Report 80-1285, 103 p.

McDonald, M.G., and Harbaugh, A.W., 1988, A modular threedimensional finite-difference ground-water flow model: U.S. Geological Survey Techniques of Water-Resources Investigations, book 6, chap. A1, 586 p.

Meyer, G.N., and Knaeble, A.R., 1995, Surficial geology: Minnesota Geological Survey County Atlas Series Atlas C-10, Part A, Stearns County, Minnesota, Plate 3.

Meyer, G.N., and Swanson, Lynn, 1996, Text supplement to the geologic atlas, Stearns County, Minnesota: Minnesota Geologi- cal Survey County Atlas Series Atlas C-10, part C, 63 p.

Miller, R.T., 1982, Appraisal of the Pelican River sandplain aquifer, western Minnesota: U.S. Geological Survey Open-File Report 82-347, 40 p.

Minnesota Department of Health, 1999, Workplan for the Cold Spring Clean Water Partnership project: Report prepared for City of Cold Spring, 70 p.

Mitton, G.B., Guttormson, K.G., Stratton, G.W., and Wakeman, E.S., 1999, Water-resources data, Minnesota, water year 1998: U.S. Geological Survey Water-Data Report MN-98-1, $410 \mathrm{p}$.

Morris, D.A., and Johnson, A.I., 1967, Summary of hydrologic and physical properties of rock and soil materials, as analyzed by the hydrologic laboratory of the U.S. Geological Survey 194860: U.S. Geological Survey Water-Supply Paper 1839-D, $42 \mathrm{p}$.

Norris, S.E., and Fidler, R.E., 1969, Hydrogeology of the Scioto River Valley near Piketon, south-central Ohio: U.S. Geological Survey Water-Supply Paper 1872, $70 \mathrm{p}$.

Pelletier, P.M., 1988, Uncertainties in the single determination of river discharge-A literature review: Canadian Journal of Civil Engineering, v. 15 , no. 5.

Pollock, D.W., 1989, Documentation of computer programs to compute and display pathlines using results from the U.S. Geological Survey modular three-dimensional finite-difference groundwater flow model: U.S. Geological Survey Open-File Report 89-381, $188 \mathrm{p}$.

Prince, K.R., Franke, O.L., and Reilly, T.E., 1987, Quantitative assessment of the shallow groundwater flow-system associated 
with Connetquot Brook, Long Island, New York: U.S. Geological Survey Water-Supply Paper 2309, 28 p.

Rasmussen, W.C., and Andreasen, G.G., 1959, Hydrologic budget of the Beaver Dam Creek Basin, Maryland: U.S. Geological Survey Water-Supply Paper 1472, 106 p.

Setterholm, D.R., 1995, Depth to bedrock and thickness of Creta- ceous strata: Minnesota

Geological Survey County

Atlas Series Atlas C-10, Part A,

Stearns County, Minnesota,

Plate 5.

U.S. Environmental Protection Agency, 1987, Guidelines for delineation of wellhead protection areas: U.S. Environmental Protection Agency Office of Ground-Water Protection, Washington, D.C., EPA 440/6-
87-010, 189 p.

1996, Drinking water regulations and health advisories:

U.S. Environmental Protection Agency, February, 11 p.

Yager, R.M., 1993, Estimation of hydraulic conductivity of a riverbed and aquifer system on the Susquehanna River in Broome County, New York: U.S. Geological Survey WaterSupply Paper 2387, 49 p. 


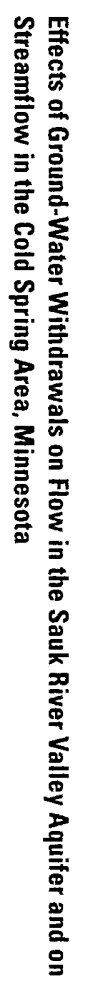

